\title{
An Overview of Quality of Urban Life in Konya (Turkey) from the Perspectives of Experts via Analytical Hierarchy Process (AHP)
}

\author{
Fadim Yavuz ${ }^{\circ}$ \\ Assoc. Prof. Dr., Faculty of Fine Arts and Architecture, Necmettin Erbakan University, Konya, Turkey. Email: \\ fadimyavuz@erbakan.edu.tr
}

\begin{abstract}
Purpose

This study mainly aims to evaluate comparatively the Quality of Urban Life (QoUL) in Konya city on the basis of Karatay, Meram and Selçuklu districts from the perspectives of two expert groups and to show the suitability of Analytical Hierarchy Process (AHP) methodology for QoUL Assessment.

Design/Methodology/Approach

In the scope of the study, AHP has been utilized to explore the importance weights of each and overall performances of QoUL criteria in the hierarchy in terms of 19 sub-criteria of 5 criteria groups of "Environmental Quality, Physical Quality, Functional Quality, Safer Places, and Social Connection and Interaction at Micro and Macro Environment" from the perspectives of local authority experts and academicians.

Findings

The expert groups have determined different priority weights on the basis of the criteria groups and sub-criteria, and also each district have different criteria performance scores separately. However, the multi-criteria district-based overall QoUL priority rankings of both expert groups are same with different weight rates. Meram is the district with the highest quality of life (QoL), while Karatay is the district with the lowest QoL from the perspective of expert groups.

Research Limitations/Implications

The outputs of the methodology contribute to a better understanding of comparative QoUL performances of three districts via comparing each of them in terms of each QoUL criteria from the perspectives of experts for decision-makers. However, the lack of inhabitant opinions of the city for an overall participatory QoUL assessment is the limitation of the study. Thus, studies focusing on inhabitants" views have potential to valuable contribution to further researches and urban planning \& design applications.

\section{Social/Practical Implications}

In practice, the manuscript has potential to guide local government units and other relevant stakeholders regarding with appropriate actions and transformations to increase the QoUL and create urban areas with high QoUL. The widespread use of the proposed QoUL assessment methodology, which is adaptable for other cities to a significant QoUL evaluation, can lead to a better participatory planning process and finally more qualified urban environments thus can enhance QoUL.

\section{Originality/Value}

The study presents a rational and adaptive QoUL assessment approach for local authorities, relevant occupation disciplines and researchers who aim to enhance QoUL.
\end{abstract}

Keywords: Analytical Hierarchy Process (AHP), Konya, liveability, quality of urban life, quality of urban life assessment 


\section{INTRODUCTION}

The deterioration of many urban environments due to increasing number and size of cities have led to a growing concern regarding the problems of city for the future of cities and for the well-being of city dwellers (Pacione, 2003). Enhancing the QoUL of residents has become a fundamental component in the urban growth management strategies of many cities (Allen, 2016) as a response to the confronted urban problems. There has been growing public interest in understanding the relationships between the economic, environmental and social aspects of life (DIT, 2012). Increasing population in cities has increased the importance of researches examine the relationship between the qualities and characteristics of an urban setting and the perceived satisfaction of its users (MacLean \& Salama, 2019) via QoUL concept, which is a multidimensional and interdisciplinary notion (Papachristou \& Rosas-Casals, 2015; Włodarczyk, 2015) that is able to monitor the multi-dimensional nature of cities (Psatha et al., 2011).

Liveable cities support the health, wellbeing and QoL of people who live and work in them. The way they are planned, designed, built and managed can enhance or detract from liveability. The physical characteristics that contribute to the liveability of cities include land use, built form, quality and conservation of public spaces and natural environments, efficiency of transport networks, accessibility to work, education, health and community services and social and recreational opportunities (DIT, 2012). Lowe et al. (2013) suggests that liveable places are safe, attractive, socially cohesive and inclusive, environmentally sustainable, affordable and diverse housing, easy access via convenient public transport, walking and cycling infrastructure to urban amenities such as education, public open space, local shops, health and community services, leisure and cultural opportunities. The relevant literature points out the relationship between liveability and the quality of space and the built environment (ACE, 2019; Carmona, 2019; Parkinson et al., 2006).

Measurement of QoUL is a complex multi-dimensional process due to multiple criteria and multiple stakeholders it involves. Multi-criteria decision-making (MCDM) methods can considerably serve as beneficial decision support systems for measurement of QoUL. AHP is a structured MCDM technique for organizing and analysing complex decisions, based on mathematics and psychology (Ganebnykh et al., 2019). AHP simplifies complex and multi-criteria decision-making process, thus leads to better decisions determining most appropriate solutions in a clear and rational way (Ganebnykh et al., 2019; Harker \& Vargas, 1987; Lotfi \& Solaimani, 2009; Onnom et al., 2018).

Current study aims to evaluate QoUL of Konya city's three districts comparatively from the perspective of two expert groups via an AHP based QoUL assessment methodology. As part of the assumption of "welldesigned interventions in the built environment ensure social, economic, health, and environmental benefits, thus enhance the QoUL via creating 
liveable environments", QoUL assessment methodology is structured on to the five significant evaluations criteria: environmental quality, physical quality, functional quality, safer places, social connection and Interaction at Micro and macro environment. In this framework manuscript has five parts:

At "Introduction" part, the aim of the study and importance of QoUL researches were explained.

Quality of Urban Life (QoUL) notion and QoUL Assessment Criteria were handled at the "theoretical background". In this term, liveability, QoL and QoUL notions were described showing the differences between them. Additionally theoretical and methodological approaches to the conceptualizing and measuring of QoUL and the necessity of subjective and objective dimensions to measure QoUL were evaluated. QoUL Assessment Criteria, consisting "Environmental Quality, Physical Quality, Functional Quality, Safer Places, Social Connection and Interaction at Micro and macro environment", were explained comprehensively through relevant literature.

Thirdly at "Material and Methodology" part, the characteristics of Karatay, Meram and Selçuklu districts of Konya city which constitute the main material of this study were explained. Also, the advantages of AHP based QoUL assessment methodology are discussed with the review of relevant researches. Afterwards, the basics of survey were also discussed via explaining the "survey design", "survey application" and "AHP based QoUL assessment phases".

Finally, the findings of the study were presented within the scope of three evaluation principles consisting "Expert assessments regarding QoUL criteria groups", "Expert assessments regarding QoUL sub-criteria" and "Assessments of experts for QoUL in central districts of Konya city".

\section{LITERATURE REVIEW}

\section{Quality of Urban Life (QoUL) Notion}

One of the confusing things in the QoUL literature is the proliferation of notions of well-being, satisfaction, happiness (Marans, 2012; Papachristou \& Rosas-Casals, 2015), liveability, QoL and space and place quality.

Liveability reflects the wellbeing of a community and comprises the many characteristics that make a location as a place where people want to live now and in future (Lowe et al., 2013). QoL is often confused with liveability. Liveability can be regarded as a subset of QoL concept that covers a much broader range of topics such as education, poverty, economic deprivation, health, the environment and congestion (DIT, 2012).

According to Murgaš \& Klobučník (2018), QoL and QoUL are two different notions thus, the QoUL exists as an original category of QoL. QoL is the QoL of the individual, and it is secondary to where the individual lives, whether in the city or village. QoL is often considered a notion that refers both to prosperity and well-being (Włodarczyk, 2015). World Health 
Organization (WHO, 2020) defines Quality of Life as an individual's perception of their position in life in the context of the culture and value systems where they live and in relation to their goals, expectations, standards and concerns. It is a broad ranging concept affected in a complex way by the person's physical health, psychological state, personal beliefs, social relationships and their relationship to salient features of their environment. Mohit (2014) suggests that QoL can be construed from a happiness and life satisfaction approach due to the fact of happiness and life satisfaction are the central objectives of most people's well-being in life. QoL is the concept of the good life, which is lived in a good place (Murgaš \& Klobučník, 2018). Although happiness and life satisfaction are not the same, they are mutually interrelated with the notion of QoL (Mohit, 2014).

QoUL has been conceptualized by several authors (MacLean \& Salama, 2019; Marans, 2012; Marans \& Stimson, 2011; Murgaš \& Klobučník, 2018). Despite the high attractiveness of QoUL concept, it has no a generally accepted definition (Parkinson et al., 2006; Salihoğlu, 2016). However, similarities and correlations observed in QoUL measurement concepts in related literature are significant to understand OoUL.

The QoUL is a societal quality, where the key word is a place. QoUL is the good life, which is lived in a certain city as a good place. QoUL is holistic and has two dimensions - the personal, which comprises life satisfaction in a certain city, and the spatial, which comprises quality of place. External conditions create the quality of place for living a good life. Thus, QoUL approach has both subjective (well-being) and objective (quality of place) components and dimensions (Atkins et al., 2015; Marans, 2012; McCrea et al., 2005; Murgaš \& Klobučník, 2018).

The QoL at societal level is related with the capabilities and chances offered to society members in order to obtain a good personal QoL (Psatha et al., 2011). The perception of quality of life varies from person to person as well as from one place to another and from one scale to another (residential environment, city, national, international or regional) (Ministry of Development, 2018).

Atkins et al. (2015) conceives that objective QoUL factors refer to measurable and countable things such as cost of housing, climate, number of urban amenities (hospitals, schools), public transport availability, and crime level, while the subjective QoUL factors are linked to personal feelings such as likes, dislikes, social connection and beliefs, traditions and spiritual connections to places (Atkins et al., 2015).

QoUL has an objective dimension, but the assessment of this notion depends on a subjective system of values and opinions as to the extent to which people's needs and aspirations are satisfied (Włodarczyk, 2015). For many years, scholars have been arguing that "quality" of any entity has a subjective dimension that is perceptual as well as having an objective reality (Marans, 2012; Marans \& Stimson, 2011). The reviewed literature shows the importance of measurement of urban amenities in terms of objective dimension as well as subjective dimension of QoUL. 
Papachristou \& Rosas-Casals (2015) have emphasized the complementary role of objective indicators in QoUL studies. According to Dempsey (2008) it would be misleading to suggest that good, or high, quality is a wholly subjective concept. The measurement of high quality should not be limited to users'/residents' subjective opinions or satisfaction with, or perceived rating of, a good or service. The quality of spaces can also be measured objectively. Therefore, QoUL requires an understanding of both components and relationships between them (Marans, 2012) and studies addressing combination of subjective and objective dimensions of QoUL can contribute to more effective QoUL assessments (Atkins et al., 2015).

Theoretical and methodological approaches to the conceptualizing and measuring of QoUL are widely addressed with an increasing interest Michalos (2014) emphasized that since the 1960s two overlapping but fairly distinct research communities and traditions have developed concerning ideas about the quality of life, individually and collectively, one with a fairly narrow focus on health-related issues and one with a quite broad focus. QoUL studies are oriented towards subjective and objective dimensions of QoUL and QoUL measurement (Marans \& Stimson, 2011). A number of studies undertaken in this scope interpret it in a variety of ways and propose different tools and methods for measuring it. Studies investigating the QoUL vary considerably in terms of scale such as neighbourhood (Delsante, 2016; Dempsey, 2008; Din et al., 2013; Leby \& Hashim, 2010; Salihoğlu \&Türkoğlu, 2019), city (Allen, 2016; Lotfi \& Solaimani,2009; Rezvani et al., 2013; Turkoglu et al., 2006), region (Pacione, 2003), country (Sarı \& Kındap, 2018; Włodarczyk, 2015), international (such as Mercer Quality of Living Survey, the Economist Intelligent Unit's Liveability Index) and the focused measurement dimensions i.e. social, economic, environmental, physical, political and psychological and mobility (Din et al., 2013). Many different approaches of this concept can be found not only between papers of different disciplines (health sciences, social sciences or planning), but also in the context of the same scientific field (Psatha et al., 2011). Contemporaneously with the studies focusing on objective QOUL criteria (Stimson \& Marans, 2011), subjective QoUL criteria (McCrea et al., 2011) or both criteria (Allen, 2016; Merschdorf, 2014; Papachristou \& RosasCasals, 2015) in empirical researches at different scales/contexts, there are conceptual studies aiming to present an effective road map on the quality of QoUL measurement by reviewing (Lowe et al., 2013; MacLean \& Salama, 2019; Marans, 2012; Marans \& Stimson, 2011; Murgaš \& Klobučník, 2018).

In QoUL studies, different indicators are formed with selected variable set, the weights assigned to the variables, the characteristics of the area, the adopted approach and method (Salihoğlu, 2012; Sarı \& Kındap, 2018). The subjective and objective indicators of QoUL are far from having a standard (Psatha et al., 2011) due to the multidimensionality of the QoUL concept. However, some indicators and indicator titles such as 
environmental, social and economic indicators are repeated in many studies (Sarı \& Kındap, 2018).

\section{QoUL Assessment Criteria}

The QoUL assessment criteria titled as "Desirable Liveability Indicators" were set through government's 'Cleaner, Safer, Greener' programme by United Kingdom Office of the Deputy Prime Minister (OPDM). "Desirable Liveability Indicators" consisting 13 sub-liveability indicators under four main headings and concentrating on the public realm and the built environment, in terms of both observed outcomes and citizens' perceptions of their local urban environment have commonly been used in QoUL researches in England (Parkinson et al., 2006; Yeang, 2006) and in the related literature. Turan \& Erdönmez Dinçer (2017) analysed the Pariser Platz and Potsdamer Platz squares in Berlin comparatively, based on the "Desirable Liveability Indicators" of OPDM. Mousavi (2013), on the other hand, discussed the physical and social dimension of the definition of liveability dimension in measuring the liveability of historical urban environments. Five main QoUL criteria, were confronted with partially or holistically in the abovementioned literature are "Environmental Quality, Physical Quality, Functional Quality, Safer Places, Social Connection and Interaction at Micro and macro environment". Finally, these indicators explained comprehensively at below through relevant literature, have also guided the current study.

\section{Environmental quality criteria in context of QoUL}

The pressures on space, ecosystems, infrastructures, facilities and personal lifestyles due to global population growth are increasing. The importance of environmental problems, which also affect the quality of life, is increasing. Evaluation and monitoring of urban environmental quality become an important issue in decision making and planning of more liveable and sustainable cities (Krishnan \& Firoz, 2020; Silva \& Mendes, 2012). This criteria category focuses on four elements regarding environmental quality: "noise pollution", "environmental cleanliness", "crowd (human density)" and "building quality" (Parkinson et al., 2006; Yeang, 2006). Urban air pollution and urban noise are major factors that can degrade quality of life in cities. These problems generally get worsened as a result of unbalanced urban development, increase of mobility and road traffic (Silva \& Mendes, 2012). A clean and natural environment, the beauty and aesthetics of the living environment (Ganebnykh et al., 2019; Leby \& Hashim, 2010) and the observed and perceived cleanliness of the streets in the built environment are also an important environmental quality parameter. A balanced and effective distribution of population density (Leby \& Hashim, 2010; Lowe et al., 2013 ) is necessary for more liveable environments. The crowdedness of cities is also a subjective QoUL indicator. The creation of quality-built environments (architecture, street design, building quality, aesthetics etc.) should be encouraged in liveable cities (Lowe et al., 2013), buildings 
should have a high level of maintenance (Leby \& Hashim, 2010; Shamsuddin \& Abu Hassan, 2013).

\section{Physical quality criteria in context of QoUL}

Urban space and place quality and place value are intrinsically interconnected, and qualified physical environments positively affect health, social, economic and environmental outcomes, thus positively affect the quality of life for their users (Carmona, 2019; İnceoğlu \& Aytuğ, 2009). This criteria category consists of "quality of the built environment", "less abandoned spaces", "quality of parks and green spaces", "maintenance of residences and open spaces" and " public realm quality" criteria.

There is a broad consensus on the fact that a built environment highqualified positively impacts people's everyday lives (ACE, 2019; Carmona, 2019). Designing a high-quality built environment is a creative and innovative process whose final outcome has a fundamental impact on how people perceive, function and behave. Quality makes a direct contribution to our everyday lives and should be considered as an agent of change. High-qualified architecture can enrich lives of individuals and a society in different ways. High-qualified built environments, form effective interaction for the communities thus, strengthen culture and identities, support sustainable development, enable economic contribution via creating attractive spaces and creating healthy living environments (ACE, 2019). In general, high quality public spaces (pedestrian roads, squares, building interfaces, etc.) and open-green spaces contribute to the improvement of liveability by strengthening economic and environmental factors (Beck, 2009). It is important to design public spaces where communication with the city and city dwellers will be provided in while ensuring the QoUL (Tekeli et al., 2004). Therefore, quality of public spaces in terms of parameters such as design, comfort, safety and maintenance should be supported. Carmona (2019) has pointed out a very strong positive association between place derived value of all types (health, social, economic and environmental) and greenness in the built environment (notably the presence of trees and grass, water, and open space).

\section{Functional quality criteria in context of QoUL}

While the functional quality of a building is to provide appropriate level of support for the desired activities to provide appropriate economic contribution and affordable price (İnceoğlu \& Aytuğ, 2009), functional quality for the cities points out suitability of urban actions in socioeconomic and environmental context. This category covers the criteria of "convenient pedestrian circulation", "quality of public transport", "low traffic speeds \& density" and "live vitality and viability of services and urban amenities" regarding how cities and urban areas are used. While the first three criteria are indicators of liveability in themselves, the fourth criteria represent a reflection of the success of liveability in 
attracting people and businesses to a region (Parkinson et al., 2006). The relative easiness of walking and bicycle rides (transportation safety, pavement and pedestrian pathways, comfort, etc.), which is an important component of functional place quality by providing physical, environmental and economic benefits to the city and to the community, can reveal whether the urban area is pedestrian friendly. The quality of public transport (comfort, time, price policy, accessibility, route efficiency, safety, speed of public transport, distance to public transport stop, etc.) and relative assessments of traffic density (traffic speeds and traffic purge measures, transport safety, etc.) contribute to improve QoUL by detecting and eliminating problems caused by transportation. Carmona (2019), examined 271 studies on the quality of the place, pointed out that there is a very strong positive relationship between place derived value of all types (health, social, economic and environmental) and functional quality indicators such as; "the diversity of land uses (mixed uses)", "low levels of traffic", "the walkability and bikeability of places", "the use of more compact (less sprawling and fragmented) patterns of development" and "a good public transport network", etc. Vitality and viability of services and urban amenities (socio-cultural facilities, parks, infrastructure, cleanliness, etc.) in terms of accessibility, diversity, service quality and maintenance have positive effects on the vitality and life comfort level of the city. This indicator is useful in measuring people's usage levels in urban centres and the performance of the local retail business environment (Parkinson et al., 2006).

\section{Safer places criteria in context of QoUL}

In the relevant literature, indicators of crime and security perceptions are accepted as a basic requirement to ensure liveability. The areas have low crime rates and where the residents' fear of crime rates is lower are more liveable areas. Security of a place or city can be measured via objective indicators such as; crime rates (crimes against property, crimes against individuals, juvenile crime rates), street lighting level, traffic safety, domestic violence per 10,000 people, personal assault, robbery records, etc. (Ganebnykh et al., 2019; Leby \& Hashim, 2010; Lowe et al., 2013; Parkinson et al., 2006; Türkoğlu et al., 2008; Yeang, 2006) and also personal security perception indicators such life and property security, being alone at home during the day and night, walking alone at night in public places, being alone at night, etc. (Leby \& Hashim, 2010; Lowe et al., 2013; Türkoğlu et al., 2008). Leby \& Hashim (2010) evaluated accident rates and frequency as safety indicators. In this study, "safer place" criteria were evaluated with "low crime rate" and "safety of life and property".

\section{Social connection and interaction at micro and macro environment quality criteria in context of QoUL}

QoUL is a concept that expands with social quality. Family, friends, neighbours and relatives of the individual are important social support 
providers in terms of QoUL (Hollar, 2003). Social cohesion studies focusing on social connections, social relations and understanding of common benefit in social life can reveal important findings for the relationship or degree of "living together" and "social trust" for the relevant society (Ataseven \& Bakış, 2018). "The number of relatives and friends in the environment" is an objective indicator for the existence of social connection. In addition, friendship and social communication are key to human resource and participation. The second feature that connects societies is "good neighbourhood relations" (Türkoğlu et al., 2008). The concept of belonging in the urban space, as a result of the dynamic and reciprocal relationship between the individual and the environment, expresses the state of belonging to a place, where people feel right and responsible for that space. Belonging is supported by feeling of security, and there is a relationship between physical environment and personal feelings, thoughts, attitudes and societal culture (Güleç Solak, 2017). According to Özden (2010), urban sustainability can be achieved by creating socially and spatially compatible, integrated areas. At this point, social integration and harmony includes elements such as the socio-cultural, economic and spatial coexistence of a community within the framework of respect, tolerance and trust, the purification of urban tension and conflict. In this study, the criteria of "social connection and interaction at micro and macro environment" were evaluated with "the number of relatives and friends living nearby", "good neighbourhood relations", "feeling part of the community" and "ensuring social integration / harmony" sub-criteria.

\section{METHODOLOGY AND METHODS}

The main material of this study is the Meram, Karatay and Selçuklu districts located in the city centre of Konya. The method of the study is literature review and expert questionnaires which are compatible with AHP based QoUL assessment.

\section{Study Site: Konya City}

Konya, consists of 31 districts, is the largest province in Central Anatolia in terms of surface area (Figure 1). According to data of Turkey Statistical Institute (TSI, 2019) Konya province has a population of 2.232.374 and is the seventh most populous city of Turkey. The population in the central districts of Konya (Karatay, Meram, Selçuklu) is 1.346.330, which constitutes $60.3 \%$ of the population of the Konya Metropolitan Area. Selçuklu is the district has highest population (662.808; 29.69\%). The most populous other districts than Selçuklu are respectively Meram (344.546; 15.43\%) and Karatay (338.976; 15.18\%). 


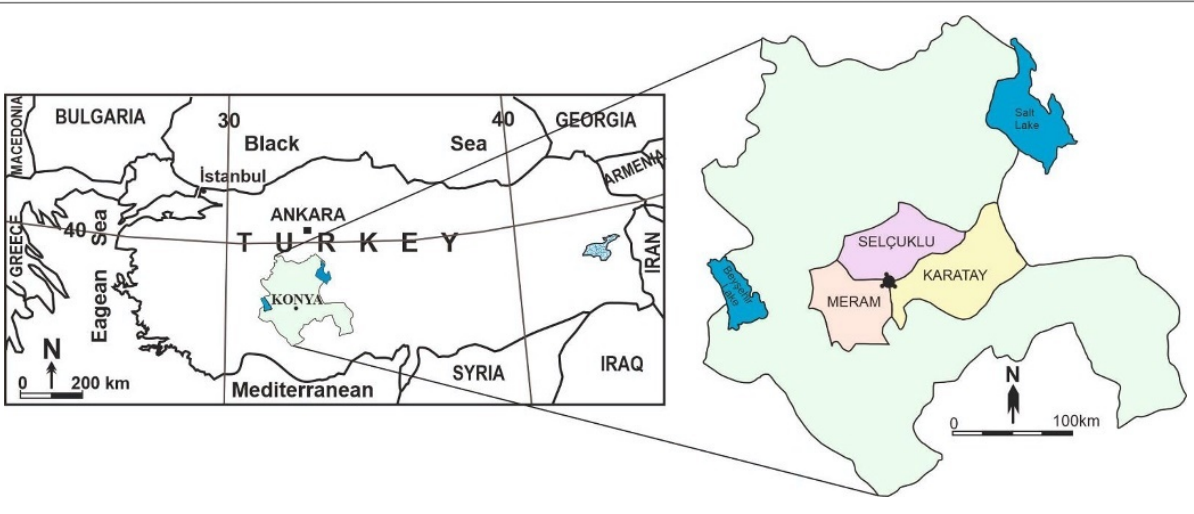

Konya, is one of the most economically developed agricultural and industrial city of Turkey. Konya, which is one of the leading places in the country in terms of agriculture, the abundance of usable lands and agricultural technologies, is the province in Turkey has the largest agricultural contribution with a share of 5.8\% (MEVKA, 2019). Besides, Konya, which hosts five universities, is also accepted as a student city. While the strong human capital infrastructure in the city leads to less costly and more efficient physical infrastructure and public services, it also makes an important contribution to the development of investment and business environment (Mangir, 2016). The city, which has a rich cultural heritage as well as natural wealth due to being the capital of Anatolian Seljukian and Karamanoğlu Principality in the historical process, has potential for multiple types of tourism as well as culture and faith tourism.

In the "Life Index Province Rankings and Index Values in the Cities in 2015" study prepared by Turkey Statistical Institute Life index indicators were handled in 11 titles with their sub-indicators. According to this study Konya is at $18^{\text {th }}$ rank of 81 provinces in Turkey with the overall index value of 0.6163 while the provinces of Isparta [0,6745], Sakarya $[0,6737]$, Bolu [0,6553], Kütahya $[0,6520]$ and Istanbul $[0,6494]$ are in the top 5, while Ankara is in the 17th place [0,6190], while İzmir is ranked 21st [0,5996].

\section{Characteristics of Karatay, Meram and Selçuklu districts}

Karatay is the district where traditional Konya urban texture is located in. There are 1-2 storey houses having semi-rural character at low density in the urban periphery. However, 6 and 8 storey, high density residential environment is being created in new settled and / or urban renewal areas. Meram where population density has increased in recent years also is the greenest district. There are residential areas at very low density in the county has a natural protected status. Multi-storey (more than 10 storey) houses are being built in urban transformation areas such as Ahmet Özcan and Şefik Can Streets also at the Havzan District. There are scattered residential areas at the southern of the district. Selçuklu is the latest constructed district of Konya where the high-storey buildings mostly exist in. There are two sub-centers-Bosna Hersek and bus station
Figure 1. Location of Konya City and Central Districts (illustration: author) 
sub-centers- which have high population density in Selçuklu. In addition, Yazır neighborhood consisting prestige residences has the highest population density in Selçuklu county (Yavuz, 2021).

Serdaroğlu Sağ (2021) conducted a study in Konya focused on assessing urban development and sprawl for the period between 1985 and 2020, states that Konya underwent a rapid urban growth in time and the physical growth of the city has had an expanding and disorganized manner for the last 30 years. In line with population growth of Karatay, Meram and Selçuklu districts, residential and non-residential constructions have increased. The construction permits issued for Selçuklu (40\%) in period of 2009-2019, are much more than the construction permits issued for Karatay (31\%) and Meram (29\%) (Yavuz, 2021) (Figure 2). In terms of QoUL, this population and construction increase have positive consequences such as improved living conditions in residential areas, vitality of services and urban amenities, differentiated living, working and entertainment areas, etc. However, it has negative consequences such as decreased environmental quality due to the high-density built-up environment, decreased social connection and interaction due to gated communities, etc.

Figure 2. Built Up Area Development Comparison of Karatay, Meram and Selçuklu (Prepared via Turkish Statistical Institute data of 2009-2019 construction permits)

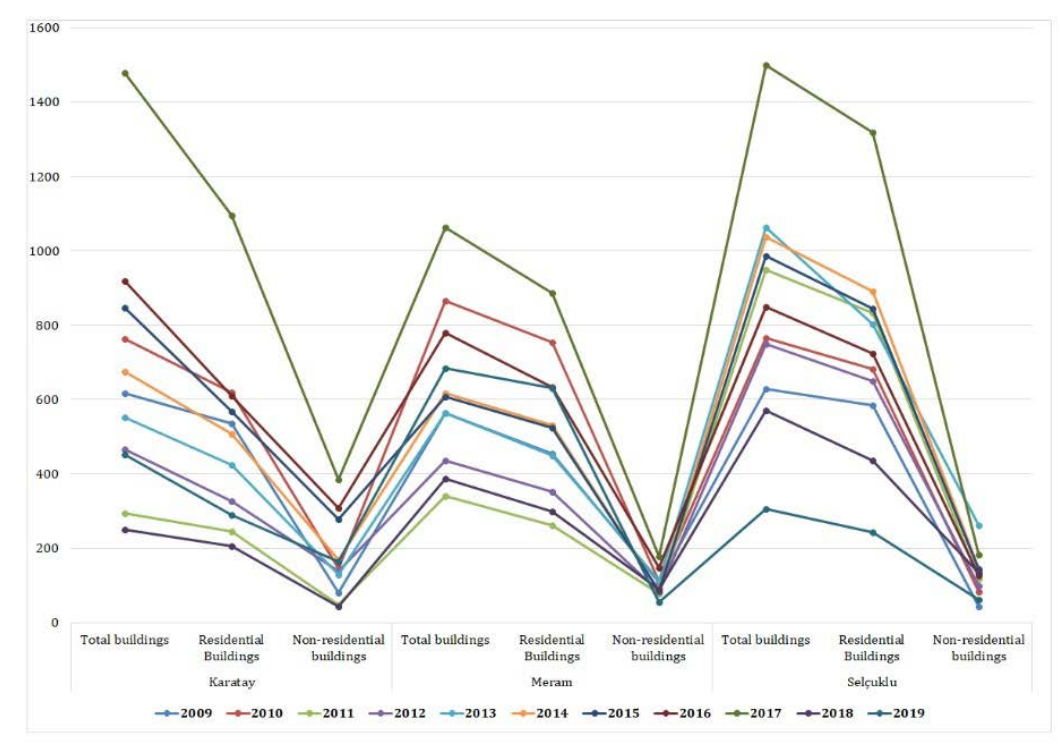

Karakayacı \& Karakayacı (2019), aimed to search the impact of urbanization pressure on the farmland in Konya, explained the spatial growth process of Konya urban region and its spatial, social and economic structure via 9 sub-regions (Figure 3). Their findings also give an idea about the status of Karatay, Meram and Selçuklu districts in terms of QoUL criteria below: i) In terms of "environmental quality" criteria status of the district being more or less congested and building quality. ii) In terms of "physical quality" criteria such as quality of the built environment (high- or low-density residential areas, scattered built-up environment), quality of parks and green spaces and public realm quality. 
iii) In terms of "functional quality" criteria status of the vitality and viability of services and urban amenities such as the status of public transportation (strong or poor) and existence of public institutions (university, business districts etc.). iv) In terms of "social connection and interaction at micro and macro environment" criteria the characteristics of the built environment (such as scattered settlements, gated community development, harmony and inconsistency in the spatial distribution of income groups, etc.) to ensure social integration / harmony.

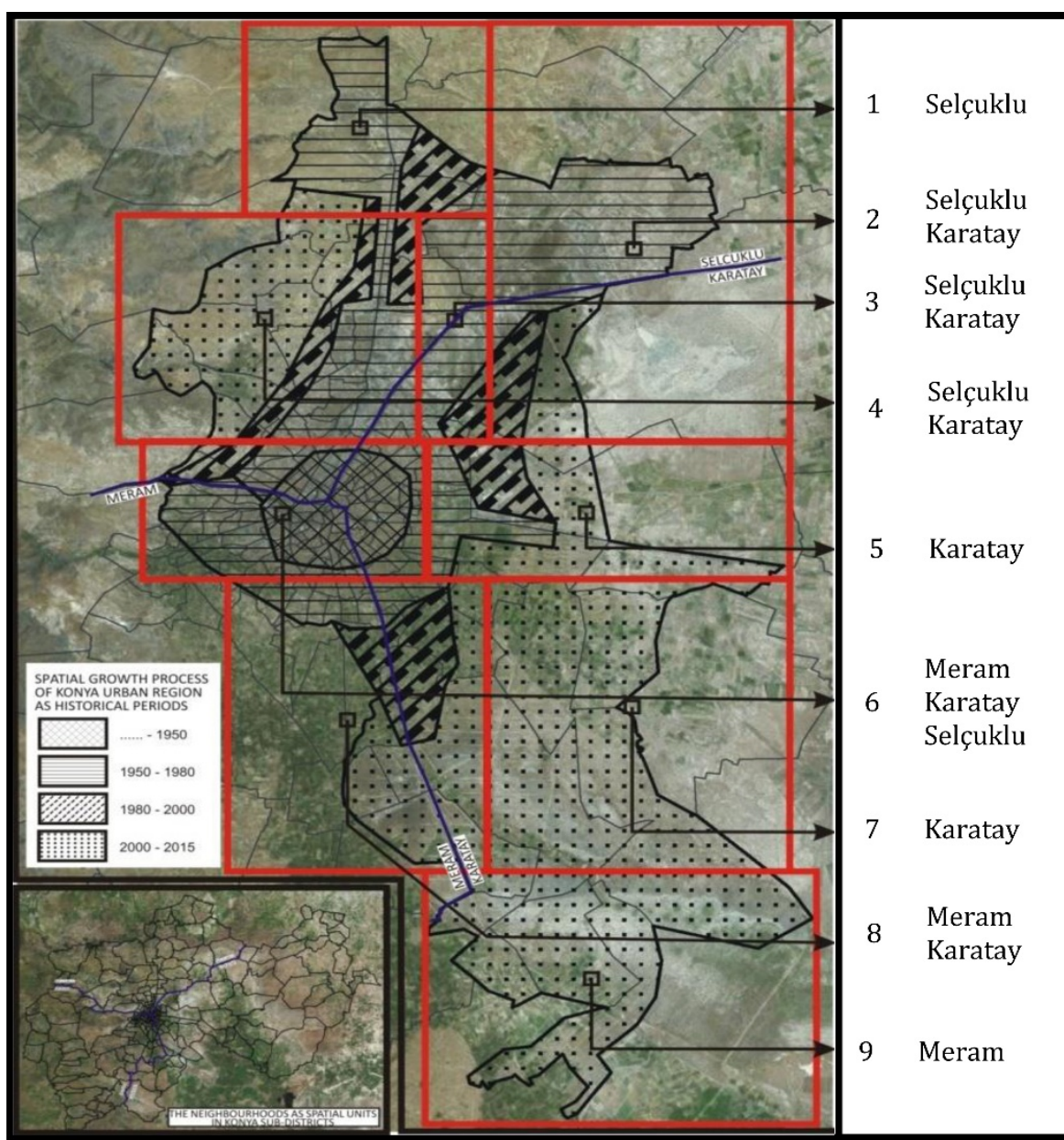

Characteristics: 1. University area, dense student population, middle-low income, the strong public transportation, sub-business centre; 2. Industrial and military areas, airport, urban parks, the strong transportation connections; 3 . Middle income, the strong public transportation; 4. Dense student population, middle income, the strong public transportation, sub-business centre, gated community growth, etc.; $\mathbf{5}$. Industrial areas, publics institutions, new university areas, urban parks, the strong transportation connections and public transportation; 6. Central business district, publics institutions, new university areas, high income and residential areas, the strong transportation connections and public transportation, etc.; 7. Low income, agricultural land, poor public transportation, scattered built -up environment; 8 . Middle low income, agricultural land, public transportation, green areas, low-dense residential areas; 9. Low income, agricultural land, poor public transportation, scattered built -up environment, rural activities, passive green areas.

\section{QoUL Assessment via AHP}

AHP, a multicriteria decision making approach in which factors are arranged in a hierarchy structure (Saaty, 1990) was developed by
Figure 3. Spatial growth process and characteristics of Konya's central districts (Adapted from Karakayacı \& Karakayacl, 2019) 
Thomas Saaty in 1980 and it has proven to be an extremely useful method for decision making and planning (Harker \& Vargas, 1987). The AHP offers a systematic approach in defining stakeholder goals and preferences in the solution process of complex, multi-criteria and multistakeholder decision problems (Sitorus et al., 2019). AHP is commonly used as a decision support system in a wide range of uses, both for individual and group decision-making because of its applicability, correctness, theoretical suitability, and capacity for addressing any intangible and tangible criteria (Dissanayake et al., 2020).

Table 1. The Relevant Literature Used AHP Methodology in QoUL Assessment

\begin{tabular}{|c|c|c|c|}
\hline Reference & Methodology & Aim & $\begin{array}{l}\text { Study } \\
\text { Area }\end{array}$ \\
\hline $\begin{array}{l}\text { Ganebnykh } \\
\text { et al., } 2019\end{array}$ & AHP & $\begin{array}{l}\text { To determine indicators of } \\
\text { urban development quality } \\
\text { and their weight coefficient } \\
\text { using AHP }\end{array}$ & - \\
\hline $\begin{array}{l}\text { Hoşgör et } \\
\text { al., } 2016\end{array}$ & AHP & $\begin{array}{l}\text { To determine the priorities of } \\
\text { the factors that affect the } \\
\text { Quality of Work Life of } \\
\text { administrative and academic } \\
\text { personnel }\end{array}$ & $\begin{array}{l}\text { Istanbul } \\
\text { University } \\
\text { Faculty of Health } \\
\text { Sciences }\end{array}$ \\
\hline $\begin{array}{l}\text { Lotfi \& } \\
\text { Solaimani, } \\
2009\end{array}$ & AHP & $\begin{array}{l}\text { To measure and prioritize the } \\
\text { urban quality of life in the two } \\
\text { case study cities }\end{array}$ & $\begin{array}{l}\text { Two northern } \\
\text { cities of Iran }\end{array}$ \\
\hline $\begin{array}{l}\text { Antognelli \& } \\
\text { Vizzari, } \\
2016 \\
\end{array}$ & $\begin{array}{l}\text { AHP with a } \\
\text { combination of } \\
\text { GIS techniques }\end{array}$ & $\begin{array}{l}\text { To get the overall liveability } \\
\text { index map }\end{array}$ & Italy \\
\hline Chen, 2020 & $\begin{array}{l}\text { AHP in } \\
\text { combination } \\
\text { with other } \\
\text { techniques such } \\
\text { as Hopfield } \\
\text { neural network, } \\
\text { TOPSIS, Gini, } \\
\text { PCA, fuzzy } \\
\text { Borda, and TS } \\
\text { fuzzy neural } \\
\text { network } \\
\text { methods }\end{array}$ & $\begin{array}{l}\text { To select a } \\
\text { suitable MCDM model for } \\
\text { evaluating the liveable } \\
\text { environment of cities. }\end{array}$ & 13 cities of China \\
\hline $\begin{array}{l}\text { Dissanayake } \\
\text { et al., } 2020\end{array}$ & $\begin{array}{l}\text { AHP+gradient } \\
\text { analysis }\end{array}$ & $\begin{array}{l}\text { To create a life quality index } \\
\text { (LQI) and identify the spatial } \\
\text { distribution pattern of LQI in } \\
\text { Kandy City, Sri Lanka }\end{array}$ & $\begin{array}{l}\text { Kandy City, Sri } \\
\text { Lanka }\end{array}$ \\
\hline $\begin{array}{l}\text { Hsueh \& } \\
\text { Lin, } 2018\end{array}$ & $\begin{array}{l}\text { AHP+ Delphi } \\
\text { method }\end{array}$ & $\begin{array}{l}\text { To get the weight value of } \\
\text { each dimension and each } \\
\text { critical success factor of } \\
\text { urban environmental quality }\end{array}$ & Fujian, China \\
\hline $\begin{array}{l}\text { Onnom et } \\
\text { al., } 2018\end{array}$ & $\begin{array}{l}\text { AHP+Geographic } \\
\text { Information } \\
\text { System }\end{array}$ & $\begin{array}{l}\text { To develop a Liveable City } \\
\text { Index for Medium Class Cities } \\
\text { in Developing Countries }\end{array}$ & Thailand \\
\hline $\begin{array}{l}\text { Yildız et al., } \\
2019\end{array}$ & $\begin{array}{l}\text { AHP+fuzzy } \\
\text { logic+ } \\
\text { Delphi+TOPSIS }\end{array}$ & To evaluate life quality & $\begin{array}{l}\text { Thirty-one } \\
\text { member } \\
\text { countries of the } \\
\text { European Union }\end{array}$ \\
\hline
\end{tabular}

AHP based QoUL assessment methodology initiates a simple, transparent and rapid stakeholder-oriented decision support system that measures QoUL which is substantially a MCDM problem. Thus, there are many 
QoUL studies in the relevant literature, which use merely AHP (Ganebnykh et al., 2019; Hoşgör et al., 2016; Lotfi \& Solaimani, 2009) or use AHP in combination with other techniques such as fuzzy logic, TOPSIS, Delphi, GIS, ANP (Antognelli \& Vizzari, 2016; Chen, 2020; Dissanayake et al., 2020; Hsueh \& Lin, 2018; Onnom et al., 2018; Yacan, 2016; Ylldız et al., 2019) (Table 1).

\section{Survey Design and Application Survey design}

The actions of some of the experts such as architects, planners, designers, engineers are directly or indirectly effective in the formation of the built environment and the creation of (un)liveable environments. QoUL can be measured via objective evaluations of experts abovementioned and via the subjective evaluations of inhabitants of the city. Hence, in this study experts who have a direct or indirect role in planning and shaping urban spaces in the assessment are handled for Konya city centre's QoUL assessment. In this way, it is also aimed to make more effective determinations by bringing together the objective and subjective evaluations of the experts residing in the city.

Although there are three districts distinction, experts' QoUL assessments enabling the priorities or importance degrees of indicators for the district-wide were made on a macro scale instead of microenvironmental assessment such as neighbourhood being lived in. Thus, QoUL evaluations made by academicians and technical personnel working in local government units such as city planners, architects, engineers, etc., provide important contributions in terms of presenting both professionally objective data and subjective data as a resident.

This study uses AHP method to evaluate QoUL in Konya city on the basis of Karatay, Meram and Selçuklu districts from the perspectives of two expert groups (local authority experts-LAEs and academicians).

The AHP is utilized to derive importance weights for each QoUL criteria comparing in a pairwise manner and explore the each of and overall performances of QoUL criteria in the hierarchy from the perspectives of LAEs and academicians. The outputs of the methodology contribute to understand the comparative QoUL performances of the three districts via comparing each of them in terms of each QoUL criteria.

QoUL assessment criteria of the study have majorly been adopted from the "Desirable Liveability Indicators" of OPDM were confronted with partially or holistically in literature. Consequently, five main QoUL criteria group (Environmental Quality, Physical Quality, Functional Quality, Safer Places, Social Connection and Interaction at Micro and macro environment) and 19 sub-criteria (Table 2) have been developed within the scope of "determining the QoUL level of Karatay, Meram and Selçuklu districts in Konya city" through a comprehensive literature review. 
An Overview of Quality of Urban Life in Konya (Turkey) from the Perspectives of Experts via AHP

Table 2. QoUL Assessment Criteria Used in the Study

\begin{tabular}{|c|c|c|c|}
\hline $\begin{array}{l}\text { QoUL } \\
\text { criteria: }\end{array}$ & \multicolumn{2}{|c|}{ QoUL sub-criteria: } & \multirow{2}{*}{\begin{tabular}{|l|} 
Reference: \\
Leby \& Hashim, 2010; Lowe et al., \\
2013; Parkinson et al., 2006; \\
Salihoğlu, 2016; Yeang, 2006 \\
\end{tabular}} \\
\hline \multirow{4}{*}{ 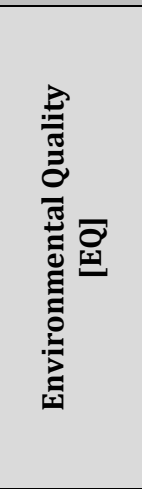 } & EQ-1 & Being noisier or quieter & \\
\hline & EQ-2 & Being dirtier or cleaner & $\begin{array}{l}\text { Leby \& Hashim, 2010; Lowe et al., } \\
\text { 2013; Parkinson et al., 2006; } \\
\text { Salihoğlu, 2016; Tapsuwan et al., } \\
\text { 2018; Yeang, 2006 }\end{array}$ \\
\hline & EQ-3 & $\begin{array}{l}\text { Being more or less } \\
\text { congested (human } \\
\text { density) }\end{array}$ & $\begin{array}{l}\text { Leby \& Hashim, 2010; Lowe et al., } \\
\text { 2013; Parkinson et al., 2006; } \\
\text { Türkoğlu et al., 2008; Yeang, } 2006\end{array}$ \\
\hline & EQ-4 & $\begin{array}{l}\text { Building quality, better or } \\
\text { worse? }\end{array}$ & $\begin{array}{l}\text { ACE, 2019; Leby \& Hashim, 2010; } \\
\text { Lowe et al., 2013; Parkinson et al., } \\
\text { 2006; Yeang, 2006 }\end{array}$ \\
\hline \multirow{5}{*}{ 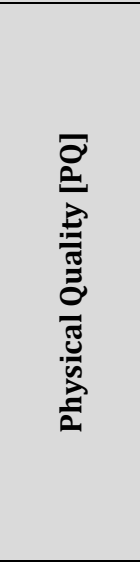 } & PQ-1 & $\begin{array}{l}\text { Quality of the built } \\
\text { environment }\end{array}$ & $\begin{array}{l}\text { ACE, 2019; Ganebnykh et al., 2019; } \\
\text { Lowe et al., 2013; Parkinson et al., } \\
\text { 2006; Shamsuddin \& Abu Hassan, } \\
\text { 2013; Yeang, } 2006\end{array}$ \\
\hline & PQ-2 & Less abandoned spaces & Parkinson et al., 2006; Yeang, 2006 \\
\hline & PQ-3 & $\begin{array}{l}\text { Quality of parks and } \\
\text { green spaces }\end{array}$ & $\begin{array}{l}\text { Carmona, 2019; Delsante, 2016; } \\
\text { Leby \& Hashim, 2010; Lombardi ve } \\
\text { ark., 2012; Lowe et al., 2013; } \\
\text { Parkinson et al., 2006; Yeang, } 2006 \\
\end{array}$ \\
\hline & $P Q-4$ & $\begin{array}{l}\text { Maintenance of } \\
\text { residences and open } \\
\text { spaces }\end{array}$ & $\begin{array}{l}\text { Leby \& Hashim, 2010; Lowe et al., } \\
\text { 2013:22; Türkoğlu et al., } 2008\end{array}$ \\
\hline & PQ-5 & Public realm quality & $\begin{array}{l}\text { Leby \& Hashim, 2010; Lowe et al., } \\
\text { 2013; Parkinson et al., 2006; Yeang, } \\
\text { 2006 }\end{array}$ \\
\hline \multirow{4}{*}{ 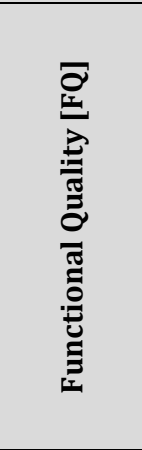 } & FQ-1 & $\begin{array}{l}\text { Convenient pedestrian } \\
\text { circulation }\end{array}$ & $\begin{array}{l}\text { Carmona, 2019; Delsante, 2016; } \\
\text { Leby \& Hashim, 2010; Lowe et al., } \\
\text { 2013; Parkinson et al., 2006; Yeang, } \\
2006\end{array}$ \\
\hline & FQ -2 & $\begin{array}{l}\text { Quality of public } \\
\text { transport }\end{array}$ & $\begin{array}{l}\text { Carmona, 2019; Delsante, 2016; } \\
\text { Lowe et al., 2013; Parkinson et al., } \\
\text { 2006; Yeang, 2006 } \\
\end{array}$ \\
\hline & FQ -3 & $\begin{array}{l}\text { Low traffic speeds } \\
\text { \&density }\end{array}$ & $\begin{array}{l}\text { Carmona, 2019; Leby \& Hashim, } \\
\text { 2010; Lowe et al, } 2013\end{array}$ \\
\hline & FQ -4 & $\begin{array}{l}\text { Vitality and viability of } \\
\text { services and urban } \\
\text { amenities }\end{array}$ & $\begin{array}{l}\text { Carmona, 2019; Leby \& Hashim, } \\
\text { 2010; Lombardi et al., 2012; } \\
\text { Parkinson et al., 2006; Yeang, } 2006\end{array}$ \\
\hline \multirow[t]{2}{*}{ 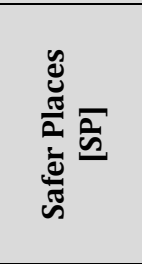 } & SP-1 & Low crime rate & $\begin{array}{l}\text { Ganebnykh et al., 2019; Leby \& } \\
\text { Hashim, 2010; Lowe et al., 2013; } \\
\text { Parkinson et al., 2006; Tapsuwan et } \\
\text { al., 2018; Türkoğlu et al., 2008; } \\
\text { Yeang, 2006 }\end{array}$ \\
\hline & SP-2 & $\begin{array}{l}\text { Safety of life and } \\
\text { property }\end{array}$ & $\begin{array}{l}\text { Leby \& Hashim, 2010; Lowe et al., } \\
\text { 2013; Türkoğlu et al., } 2008\end{array}$ \\
\hline \multirow{4}{*}{ 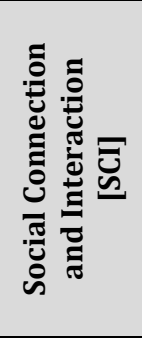 } & SCI-1 & $\begin{array}{l}\text { The number of relatives } \\
\text { and friends living nearby }\end{array}$ & Türkoğlu et al., 2008 \\
\hline & SCI-2 & $\begin{array}{l}\text { Good neighbourhood } \\
\text { relations }\end{array}$ & $\begin{array}{l}\text { Leby \& Hashim, 2010; Lowe et al., } \\
\text { 2013; Türkoğlu et al., } 2008\end{array}$ \\
\hline & SCI -3 & $\begin{array}{l}\text { Feeling part of the } \\
\text { community }\end{array}$ & Güleç Solak, 2017; Lowe et al., 2013 \\
\hline & SCI-4 & $\begin{array}{l}\text { Ensuring social } \\
\text { integration / harmony }\end{array}$ & $\begin{array}{l}\text { Choon et al., 2011; Özden, 2010; } \\
\text { Türkoğlu et al., 2008; Lowe et al., } \\
2013\end{array}$ \\
\hline
\end{tabular}


A comprehensive questionnaire compatible with AHP methodology and also consisting open ended questions have been prepared in order to measure the knowledge, experience, perceptions and approaches of the experts within the framework of research questions and related literature.

\section{Survey application}

The questionnaire was applied to the experts in two phases. Firstly, a pilot questionnaire study was applied regarding QoUL assessment scale, was used in this study. After the observation of appropriateness of the assessment scale, the number of samples was increased and a survey was conducted for two expert groups in 2018, with the goal of 100 questionnaires. 92 questionnaires were eligible for evaluation in the context of consistency, which is mentioned in the AHP systematic.

LAEs questionnaires have been applied to 73 LAEs consisting urban planners, architects and engineers working in local authorities such as Konya Metropolitan Municipality, Karatay, Meram and Selçuklu Municipalities and Provincial Directorate of Environment and Urbanization. Within the academician surveys 19 questionnaire have been applied to academicians who are urban planners, architects and topographical engineers and also live in Konya city. Urban planners are predominant in expert groups (54.3\%) (Figure 4).
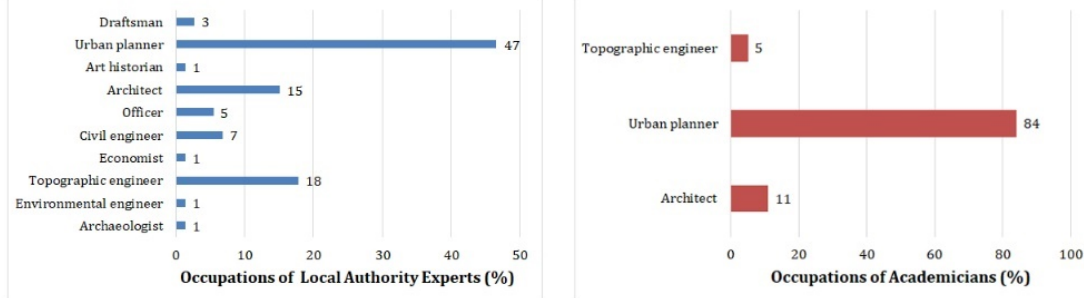

Respondent experts mostly live in Selçuklu (44.6\%), then respectively in Meram (39.1\%), Karatay (15.2\%) and other districts (1.1\%). LAEs and academicians have same priority order. However, among academicians, the rate in Meram and Selçuklu is equal (42.1\%). The rankings of "the districts where the expert groups work" are Selçuklu (48.9\%), Meram (37.0\%) and Karatay (14.0\%) similar with rankings of "the districts where experts live in".

LAEs mostly live in Selçuklu (45.2\%), then respectively in Meram (38.4\%) and Karatay (15.1\%) districts. Additionally, similar with this dispersion LAEs mostly work in Selçuklu (47.9\%), then respectively in Meram (38.4\%) and Karatay (13.7\%) (Figure 5).

The majority of academicians live in Meram (42.1\%) and Selçuklu (42.1\%) districts. The people living in Karatay are at the level of $15.1 \%$. Selçuklu $(52.6 \%)$ is in the first place among the districts studied. Academicians work in Meram are at the level of 31.6\%, and in Karatay, the working level is the lowest (15.8\%), as is the rate of living in. Data on
Figure 4. Occupations of Local Authority Experts and Academicians 
Figure 5. Counties Where Expert Groups Live and Work in $(\%)$
Figure 6. AHP Based QoUL Assessment Methodology the areas where academicians live and work show that residents of Karatay work in Karatay, but the place selections for home and workplace in Meram and Selçuklu districts differ slightly (Figure 5).

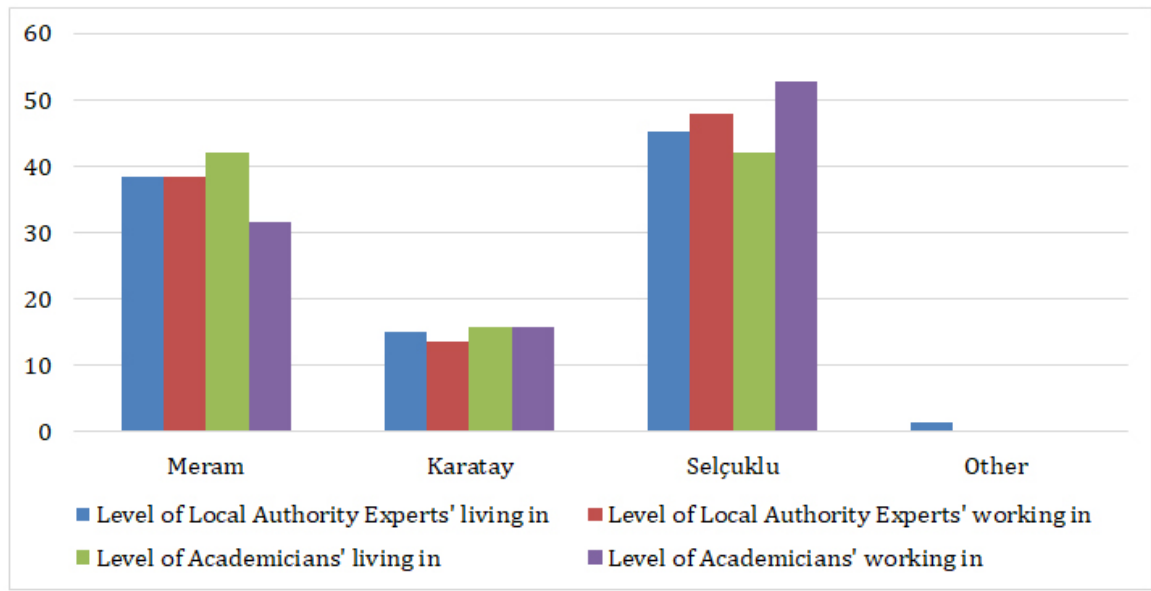

\section{Analysis: AHP based QoUL assessment}

AHP based QoUL assessment has been applied in five phases (Figure 6): (i) Structuring AHP hierarchy, ii) Performing pairwise comparisons \& local weight calculations, iii) Performing global weight calculations, and iv) Performing general priority calculations: The overall priority of an alternative suitable.

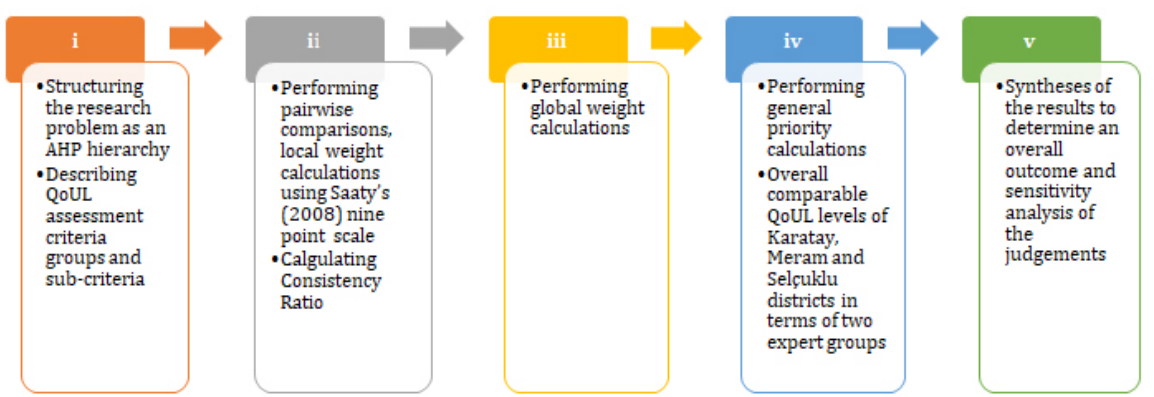

(i) Structuring the research problem as a hierarchy: The research problem \& aim of current study has been converted into an AHP hierarchical structure consisting aim, criteria groups and sub-criteria. Whereas the aim was to get a multicriteria QoUL for Konya city on the basis of Karatay, Meram and Selçuklu districts from the perspectives of two expert groups, QoUL assessment criteria groups are described in five categories such as "EQ: Environmental Quality, PQ: Physical Quality, FQ: Functional Quality, SP: Safer Places, SCI: Social Connection and Interaction at Micro and macro environment", and 19 sub-criteria [ $4 E Q, 5 P Q, 4 F Q, 2$ $S P, 4 S C I$ abovementioned and defined comprehensively in theoretical background were developed (Figure 7, Table 2). 


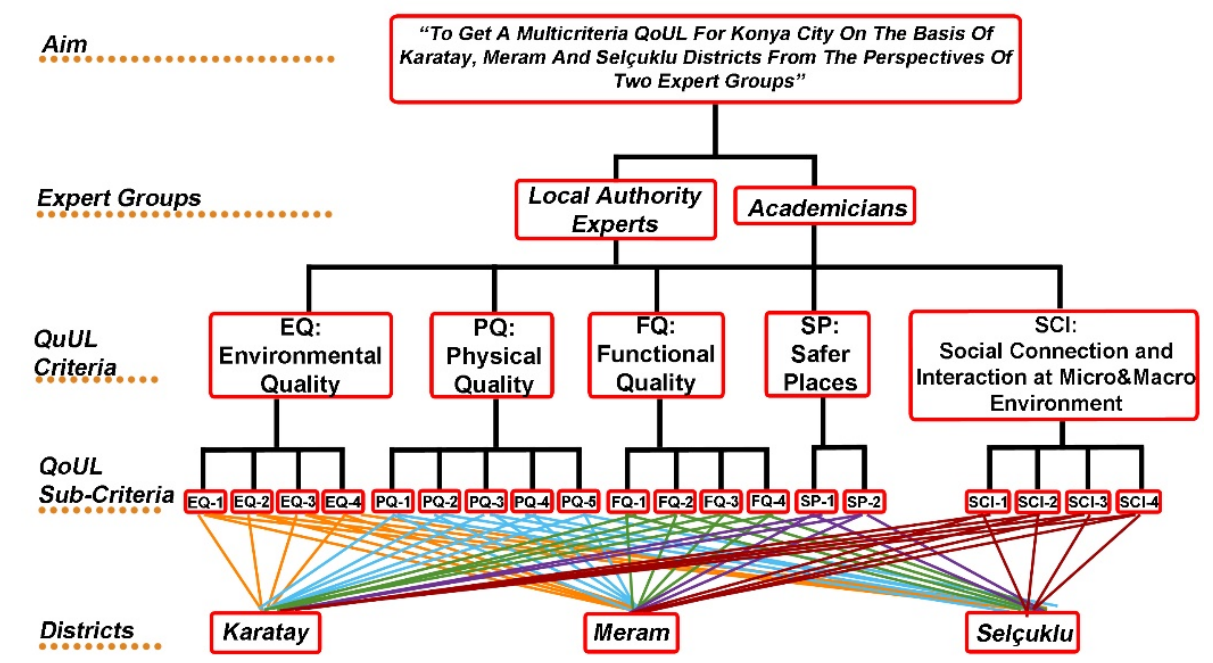

ii) Performing pairwise comparisons and local weight calculations: In this phase, pairwise comparisons of QoUL dimensions (here criteria groups) and selected QoUL sub-criteria are performed using Saaty's (2008) nine point [where 1: equal importance; 3: moderate importance; 5: strong importance; 7: very strong importance; 9: extreme importance and 2,4,6,8 are intermediate values] scale (Figure 6).

The obtained data from the survey have been evaluated via IBM SPSS (Statistical Package for the Social Sciences) Statistics program and a Microsoft Office Excel worksheet compatible with AHP calculations. In this process, if QoUL sub-criteria i.e. EQ-1 is perceived "very strong importance" than EQ-2 and is rated as 7; EQ-2 is "very less important" than EQ-1 and must be rated as 1/7. Following these comparisons, the experts' judgements were reviewed in terms of Consistency Ratio necessitates not to be equal or more than the standard limit (0.1). Finally, the relative importance and priority weights called as local weights are calculated using AHP' Eigen vector approach.

iii) Performing global weight calculations: In this phase, overall priority values \& global weights are calculated (Figure 6) through separately multiplying local weights of each QoUL criteria groups by the local weights of each of the QoUL criteria in the same group. Finally, the overall priority values of all QoUL criteria of which total value is equal to 1 are obtained.

iv) Performing general priority calculations: The overall priority of an alternative suitable for AHP hierarchy is derived via multiplying each priority of an alternative by the priority of its corresponding criteria and adding over all the criteria (Saaty, 2003). In this context, expert groups have separately evaluated status of 3 districts for each QoUL criteria in 09 scale [where 0: none; 1: very low; 3: low; 5: middle; 7: high; 9: very high; and 2,4,6,8 are intermediate values]. Consequently, overall comparable QoUL levels of Karatay, Meram and Selçuklu districts in terms of two expert groups were obtained (Figure 6).
Figure 7. AHP Hierarchy for QoUL Assessment 
v) Syntheses of the results to determine an overall outcome and sensitivity analysis of the judgements: At this phase, the overall results of AHP based QoUL assessment are discussed in terms of each expert group's judgement similarities or differences related with each of districts and QoUL criteria performance (Figure 6).

\section{RESULTS AND DISCUSSION OF THE FINDINGS}

The expert groups are satisfied with the environment they live in at the level of $82.6 \%$ in total. The satisfaction level of LAEs from the district they live in is $90.4 \%$. LAEs, who are not satisfied with the environment in which they live, mostly complain about the ignored needs of the inhabitants of the city in planning process, problems related to urban transformation and incoherent constructions. The satisfaction level of academicians with the district they live in is $52.6 \%$ while their dissatisfaction reasons are the lack of parking lots, lack of gated communities, the insufficient social facilities despite being a city centre, the insufficient infrastructure in places where the density is increased due to the plan changes, insufficiency of open areas enabling social communication and recreational activities, insufficient public transportation, excessive and noisy traffic, weak transportation facilities.

\section{Expert Assessments Regarding QoUL Criteria Groups}

Pairwise comparisons of "QoUL criteria groups" compatible with AHP technique show that "Environmental Quality" is the most important QoUL criteria from the perspective of expert groups. The expert groups then overrated the "Social Connection and Interaction at Micro and Macro Environment ", "Functional Quality", "Physical Quality" and "Safer Places" criteria groups, respectively. Although the priorities of LCAs and academicians regarding QoUL criteria groups are in the same order; LCAs more supported the "Functional Quality" and "Social Connection and Interaction at Micro and Macro Environment" criteria groups, while academicians supported the "Environmental Quality", "Physical Quality" and " Safer Places" criteria groups more (Figure 8).

Figure 8. Expert Assessments Regarding QoUL Criteria Groups (\%)

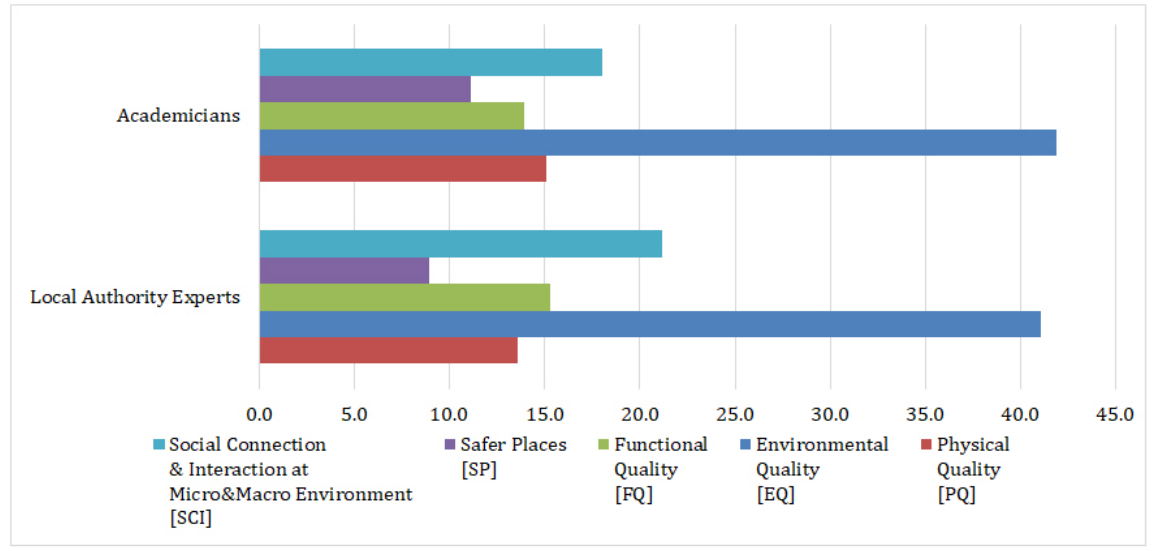




\section{Expert Assessments Regarding QoUL Sub-Criteria}

LAEs have emphasized the importance of the [EQ] "Environmental Quality" criteria category (41.1\%) in the "local weight distributions" for QoUL criteria groups. When the local weight distributions of all QoUL criteria are evaluated holistically from the perspective of $L C A s$, the most prioritized criteria are [EQ-1] "Being noisier or quieter" (16.16\%), [EQ-3] "Being more or less congested" (12.84\%) and [SCI-1] "The number of relatives and friends living nearby" (11.53\%). However, the least prioritized criteria by LAEs are [PQ-3] "Quality of parks and green spaces" (1.21\%), [PQ-4] "Maintenance of residences and open spaces" (1.40\%) and [PQ-5] "Public realm quality" (1.48\%) (Figure 9).

Academicians have also emphasized the importance of the [EQ] "Environmental Quality" criteria category (41.9\%) in the "local weight distributions" for QoUL criteria groups. When the local weight distributions of all QoUL criteria are evaluated holistically from the perspective of academicians, the most prioritized criteria are [EQ-1] "Being noisier or quieter" (17.41\%), [EQ-3] "Being more or less congested " (9.85\%) and [SCI-1] "The number of relatives and friends living nearby" (9.60\%). However, the least prioritized criteria by academicians are [PQ-5] "Public realm quality" (1.51\%), [PQ-3] "Quality of parks and green spaces" (1.53\%) and [PQ-4] "Maintenance of residences and open spaces" (2.20\%) (Figure 9).

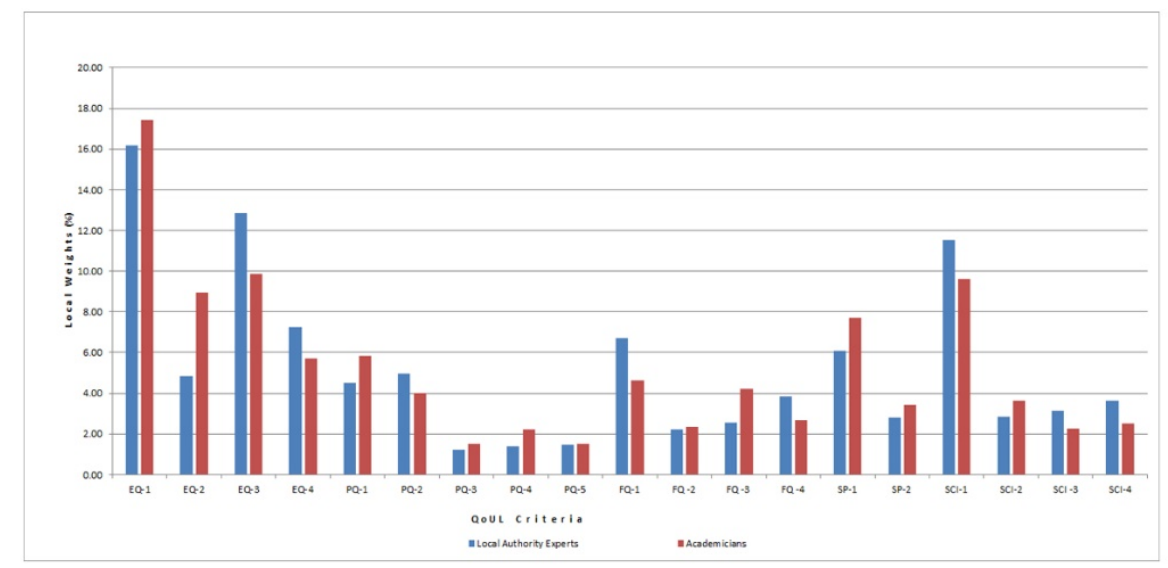

\section{Expert assessments regarding local weights of environmental quality [EQ] criteria}

[EQ-1] "Being noisier or quieter" (16.16\%) and [EQ-3] "Being more or less congested" (12.84\%) criteria have the highest priority in "Environmental Quality" category from the point of LCAs. However, [EQ2] "Being dirtier or cleaner" has the lowest priority (4.82\%). According to academicians [EQ-1] "Being noisier or quieter" (17.41\%) and [EQ-3] "Being more or less congested" (9.85\%) criteria have the highest priority in "Environmental Quality" category. However, [EQ-4] "Building quality, better or worse?" has the lowest priority (5.69\%) of academicians (Figure 10).
Figure 9. Expert Assessments Regarding Local Weights of QoUL Sub-Criteria 
Figure $\quad 10 . \quad$ Expert Assessments Regarding Local Weights of Environmental Quality [EQ] Criteria (\%)
Figure 11. Expert Assessments Regarding Local Weights of Physical Quality [PQ] Criteria (\%)

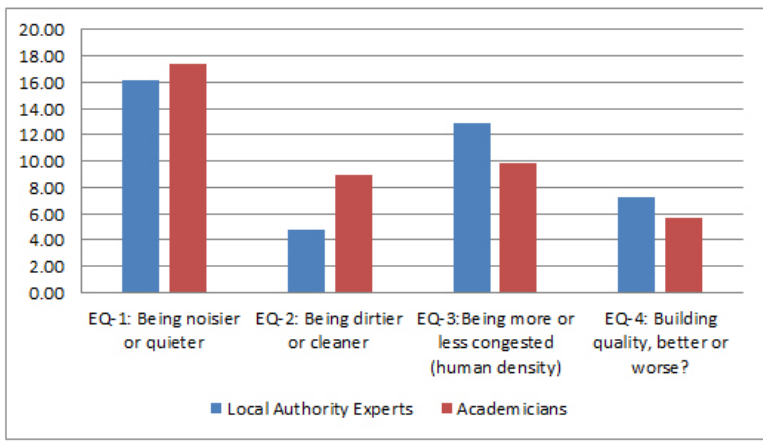

Expert assessments regarding local weights of physical quality [PQ] criteria

According to LCAs [PQ-2] "Less abandoned spaces" (4.94\%) and [PQ-1] "Quality of the built environment" (4.52\%) have the highest priority; while [PQ-3] "Quality of parks and green spaces" (1.21\%) is the least prioritized "Physical Quality" sub-criteria. According to Academicians; [PQ-1] "Quality of the built environment" (5.85\%) and [PQ-2] "Less abandoned spaces" (3.99\%) have the highest priority; while [PQ-5] "Public realm quality" (1.51\%) is the least prioritized "Physical Quality" sub-criteria (Figure 11).

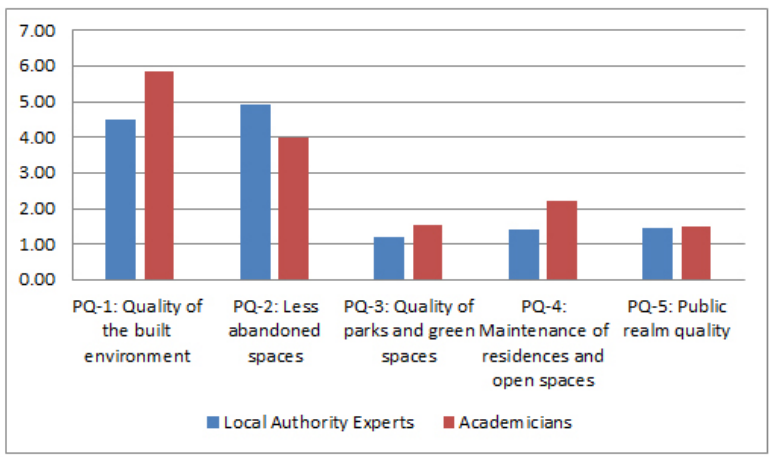

Expert assessments regarding local weights of functional quality [FQ] criteria

According to LCAs in "Functional Quality" category, the highest values are in [FQ-1] "Convenient pedestrian circulation" (6.72\%) and [FQ-4] "Vitality and viability of services and urban amenities" (3.82\%). [FQ-2] "Quality of public transport" is the least prioritised (2.22\%) sub-criteria by LCAs in this category. According to Academicians in "Functional Quality" category, the highest values are in [FQ-1] "Convenient pedestrian circulation" (4.61\%) and [FQ-3] "Low traffic speeds \&density" (4.23\%). However, [FQ-2] "Quality of public transport" is the least prioritized (2.36\%) criteria in this category (Figure 12). 


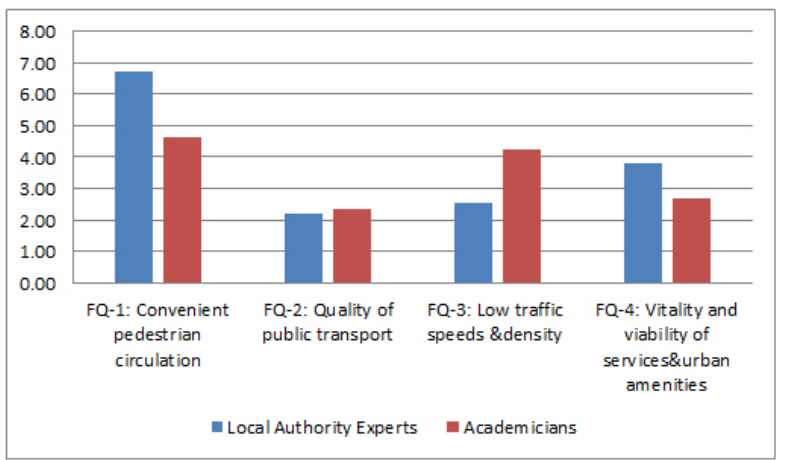

Figure 12. Expert Assessments Regarding Local Weights of Functional Quality [FQ] Criteria (\%)

Expert assessments regarding local weights of safer places [SP] criteria

In terms of "Safer Places" [SP-1] "Low crime rate" are considered more important (6.08\%) than the [SP-2] "Safety of life and property" (2.82\%) criteria by LCAs. According to Academicians in terms of "Safer Places" [SP1] "Low crime rate" are considered more important (7.72\%) than the [SP2] "Safety of life and property" (3.42\%) sub-criteria by academicians (Figure 13).

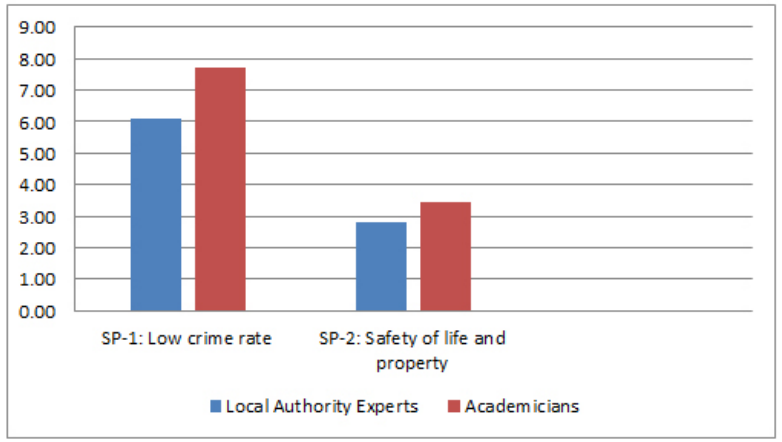

Figure $13 . \quad$ Expert Assessments Regarding Local Weights of Safer Places [SP] Criteria (\%)

\section{Expert assessments regarding local weights of social connection and interaction at micro and macro environment $[\mathrm{SCI}]$ criteria}

According to LCAs; In "Social Connection and Interaction at Micro and macro environment" category, the importance of [SCI-1] "The number of relatives and friends in the environment" has been emphasized (11.53\%), while [SCI-2] "Good neighbourhood relations" has been least prioritized (2.83\%). In "Social Connection and Interaction at Micro and Macro Environment" category, the importance of [SCI-1] "The number of relatives and friends in the environment" (9.60\%) and [SCI-2] "Good neighbourhood relations" have been emphasized (3.65\%) by academicians. However, [SCI-3] "Feeling part of the community" has been least prioritized (2.27\%) (Figure 14$)$. 
Figure 14. Expert Assessments Regarding Local Weights of Social Connection and Interaction at Micro and macro environment [SCI] Criteria

Figure 15. Expert Assessments Regarding Global Weights of QoUL SubCriteria
An Overview of Quality of Urban Life in Konya (Turkey) from the Perspectives of Experts via AHP

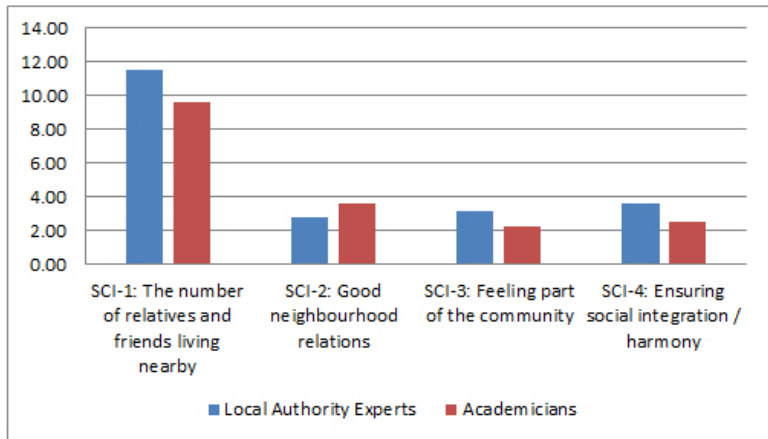

Global weight distributions of both expert groups have similar priority rank with their own local weight distributions (Figure 15).

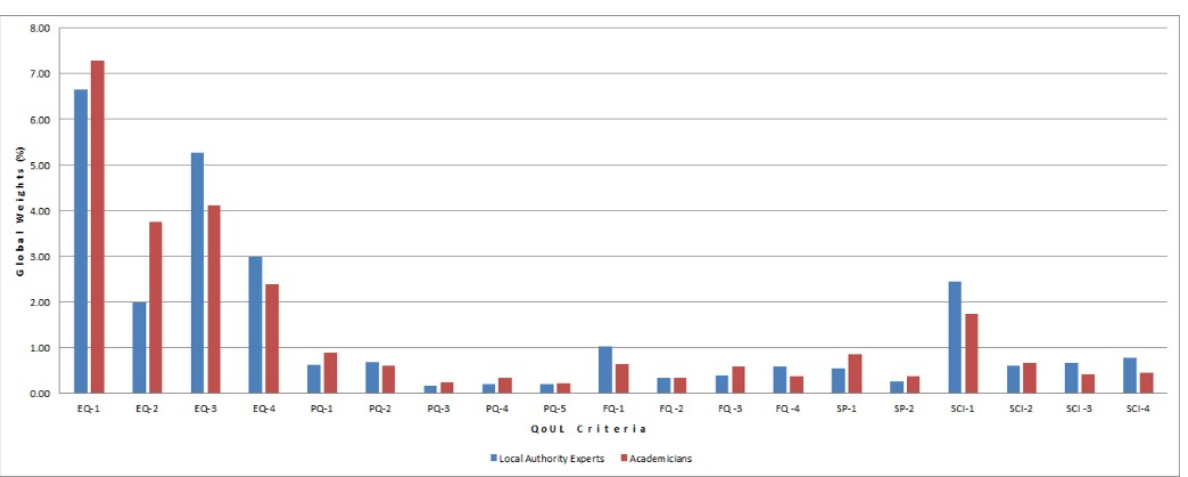

Table 3. Assessments of Experts for QoUL Criteria Importance Weights

\begin{tabular}{|c|c|c|c|c|c|c|c|c|}
\hline \multirow[b]{2}{*}{ Criteria } & \multicolumn{4}{|c|}{ Local Weights (\%) } & \multicolumn{4}{|c|}{ Global Weights (\%) } \\
\hline & $\begin{array}{c}\text { Local } \\
\text { Authority } \\
\text { Experts }\end{array}$ & Rank & Academicians & Rank & $\begin{array}{c}\text { Local } \\
\text { Authority } \\
\text { Experts }\end{array}$ & Rank & Academicians & Rank \\
\hline EQ-1 & 16,16 & 1 & 17,41 & 1 & 6,64 & 1 & 7,29 & 1 \\
\hline EQ-2 & 4,82 & 4 & 8,94 & 3 & 1,98 & 4 & 3,75 & 3 \\
\hline EQ-3 & 12,84 & 2 & 9,85 & 2 & 5,28 & 2 & 4,13 & 2 \\
\hline EQ-4 & 7,25 & 3 & 5,69 & 4 & 2,98 & 3 & 2,38 & 4 \\
\hline PQ-1 & 4,52 & 2 & 5,85 & 1 & 0,61 & 2 & 0,88 & 1 \\
\hline PQ-2 & 4,94 & 1 & 3,99 & 2 & 0,67 & 1 & 0,6 & 2 \\
\hline PQ-3 & 1,21 & 5 & 1,53 & 4 & 0,16 & 5 & 0,23 & 4 \\
\hline PQ-4 & 1,4 & 4 & 2,2 & 3 & 0,19 & 4 & 0,33 & 3 \\
\hline PQ-5 & 1,48 & 3 & 1,51 & 5 & 0,2 & 3 & 0,23 & 5 \\
\hline FQ-1 & 6,71 & 1 & 4,61 & 1 & 1,03 & 1 & 0,64 & 1 \\
\hline FQ -2 & 2,22 & 4 & 2,36 & 4 & 0,34 & 4 & 0,33 & 4 \\
\hline FQ -3 & 2,56 & 3 & 4,23 & 2 & 0,39 & 3 & 0,59 & 2 \\
\hline FQ -4 & 3,82 & 2 & 2,69 & 3 & 0,59 & 2 & 0,37 & 3 \\
\hline SP-1 & 6,08 & 1 & 7,72 & 1 & 0,54 & 1 & 0,86 & 1 \\
\hline SP-2 & 2,82 & 2 & 3,42 & 2 & 0,25 & 2 & 0,38 & 2 \\
\hline SCI-1 & 11,53 & 1 & 9,6 & 1 & 2,44 & 1 & 1,73 & 1 \\
\hline SCI-2 & 2,83 & 4 & 3,65 & 2 & \begin{tabular}{|l|}
$\square 0,6$ \\
\end{tabular} & 4 & 0,66 & 2 \\
\hline SCI -3 & $\square 3,15$ & 3 & 2,27 & 4 & \begin{tabular}{|l|}
0,67 \\
\end{tabular} & 3 & 0,41 & 4 \\
\hline SCI-4 & 3,64 & 2 & 2,5 & 3 & 0,77 & 2 & 0,45 & 3 \\
\hline
\end{tabular}

* Color scales have been prepared based on the QoUL criteria groups.

In terms of overall global weight dispersions, all the environmental quality criteria such as [EQ-1] "Being noisier or quieter", [EQ-2] "Being dirtier or cleaner", [EQ-3] "Being more or less congested" and [EQ-4] "Building quality, better or worse?", and also the criteria of [SCI-1] "Number of 
relatives and friends in the environment" are the top 5 prioritized QoUL criteria by both expert groups. Although, the least prioritized QoUL criteria by both expert groups in terms of overall global weight dispersions are [PQ-3] "Quality of parks and green spaces", [PQ-4] "Maintenance of residences and open spaces", [PQ-5] "Public realm quality", [FQ-2] "Quality of public transport", [FQ-3] "Low traffic speeds and density", [FQ-4] "Vitality and viability of services and urban amenities" and [SP-2] "Safety of life and property". Priority rankings of these criteria, whose weight values are approximate, differ slightly within their own criteria groups (Figure 15, Table 3).

\section{Assessments of Experts for QoUL in Central Districts of Konya City (Karatay, Meram and Selçuklu)}

Following the weight determinations for QoUL criteria, both expert groups have separately evaluated status of 3 districts for each QoUL criteria via rating them in 0-9 scale [where 0: none; 1: very low; 3: low; 5: middle; 7: high; 9: very high; and 2, 4, 6, 8 are intermediate values]. The scores of the expert groups for each criterion were included in the calculation as group decision with arithmetic mean. In the holistic evaluations of the experts on the district-based QoUL situation in Konya with a multi-criteria approach (Table 4, Table 5); LAEs and academicians agree that QoUL in the context of criteria Meram is more successful [LAEs: 38.5\%; Academicians: 41.6\%] than respectively Selçuklu [LAEs: 35.1\%; Academicians: 34.5\%] and Karatay [LAEs: 26.4\%; Academicians: $23.9 \%]$ districts.

Table 4. LAEs' Assessments Regarding the QoUL in Central Districts of Konya City (Karatay, Meram and Selçuklu)

\begin{tabular}{|c|c|c|c|c|c|c|c|c|c|}
\hline $\begin{array}{l}\text { QoUL Criteria } \\
\text { Groups }\end{array}$ & Weight & \multicolumn{3}{|c|}{ QoUL Sub-Criteria } & \begin{tabular}{|l|} 
Local \\
Weight
\end{tabular} & \begin{tabular}{|c|} 
Global \\
Weight \\
\end{tabular} & Karatay & Meram & Selçuklu \\
\hline \multirow{4}{*}{$\begin{array}{c}\text { Environmental } \\
\text { Quality } \\
\text { [EQ] }\end{array}$} & \multirow{4}{*}{0,411} & EQ-1 & Being noisier or quieter & 1 & 0,162 & 0,066 & 4 & 7 & 4 \\
\hline & & EQ-2 & Being dirtier or cleaner & 4 & 0,048 & 0,020 & 4 & 6 & 6 \\
\hline & & EQ-3 & Being more or less congested (human density) & 2 & 0,128 & 0,053 & 5 & 5 & 7 \\
\hline & & EQ-4 & Building quality, better or worse? & 3 & 0,072 & 0,030 & 4 & 6 & 6 \\
\hline \multirow{5}{*}{$\begin{array}{c}\text { Physical } \\
\text { Quality } \\
\text { [PQ] }\end{array}$} & \multirow{5}{*}{0,136} & PQ-1 & Quality of the built environment & 2 & 0,045 & 0,006 & 4 & 6 & 6 \\
\hline & & PQ-2 & Less abandoned spaces & 1 & 0,049 & 0,007 & 4 & 5 & 5 \\
\hline & & PQ-3 & Quality of parks and green spaces & 5 & 0,012 & 0,002 & 5 & 6 & 6 \\
\hline & & PQ-4 & Maintenance of residences and open spaces & 4 & 0,014 & 0,002 & 5 & 7 & 7 \\
\hline & & PQ-5 & Public realm quality & 3 & 0,015 & 0,002 & 4 & 6 & 6 \\
\hline \multirow{4}{*}{$\begin{array}{c}\text { Functional } \\
\text { Quality } \\
\text { [FQ] }\end{array}$} & \multirow{4}{*}{0,153} & FQ-1 & Convenient pedestrian circulation & 1 & 0,067 & 0,010 & 4 & 6 & 5 \\
\hline & & FQ -2 & Quality of public transport & 4 & 0,022 & 0,003 & 5 & 6 & 6 \\
\hline & & FQ -3 & Low traffic speeds \&density & 3 & 0,026 & 0,004 & 5 & 5 & 4 \\
\hline & & FQ -4 & Vitality and viability of services\&urban amenities & 2 & 0,038 & 0,006 & 4 & 5 & 5 \\
\hline \multirow{2}{*}{$\begin{array}{c}\text { Safer Places } \\
\text { [SP] }\end{array}$} & \multirow{2}{*}{0,089} & SP-1 & Low crime rate & 1 & 0,061 & 0,005 & 4 & 6 & 5 \\
\hline & & SP-2 & Safety of life and property & 2 & 0,028 & 0,003 & 4 & 6 & 5 \\
\hline \multirow{4}{*}{$\begin{array}{l}\text { Social Connection } \\
\text { and Interaction at } \\
\text { Micro\&Macro } \\
\text { Environment } \\
\text { [SCI] }\end{array}$} & \multirow{4}{*}{0,212} & SCI-1 & The number of relatives and friends living nearby & 1 & 0,115 & 0,024 & 4 & 6 & 5 \\
\hline & & SCI-2 & Good neighbourhood relations & 4 & 0,028 & 0,006 & 4 & 5 & 5 \\
\hline & & SCI -3 & Feeling part of the community & 3 & 0,031 & 0,007 & 5 & 6 & 5 \\
\hline & & SCI-4 & Ensuring social integration / harmony & 2 & 0,036 & 0,008 & 4 & 6 & 6 \\
\hline \multicolumn{7}{|c|}{ Total Weight: } & 0,264 & 0,385 & 0,351 \\
\hline \multicolumn{7}{|c|}{ Normalized relative importance weight (\%): } & 26,4 & 38,5 & 35,1 \\
\hline \multicolumn{7}{|c|}{ R a n k i n $g:$} & 3 & 1 & 2 \\
\hline
\end{tabular}


An Overview of Quality of Urban Life in Konya (Turkey) from the Perspectives of Experts via AHP

Table 5. Academicians' Assessments Regarding the QoUL in Central Districts of Konya City (Karatay, Meram and Selçuklu)

\begin{tabular}{|c|c|c|c|c|c|c|c|c|c|}
\hline \multirow{5}{*}{$\begin{array}{c}\text { QoUL Criteria Groups } \\
\text { Environmental } \\
\text { Quality } \\
\text { [EQ] }\end{array}$} & \multirow{5}{*}{$\begin{array}{r}\text { Weight } \\
0,419\end{array}$} & \multicolumn{3}{|c|}{ QoUL Sub-Criteria } & \multirow{2}{*}{$\begin{array}{c}\begin{array}{c}\text { Local } \\
\text { Weight }\end{array} \\
0,174 \\
\end{array}$} & \multirow{2}{*}{\begin{tabular}{|c|}
$\begin{array}{c}\text { Global } \\
\text { Weight }\end{array}$ \\
0,073 \\
\end{tabular}} & \multirow{2}{*}{\begin{tabular}{|c|} 
Karatay \\
3 \\
\end{tabular}} & \multirow{2}{*}{\begin{tabular}{|c|} 
Meram \\
7 \\
\end{tabular}} & \multirow{2}{*}{$\frac{\text { Selçuklu }}{4}$} \\
\hline & & EQ-1 & Being noisier or quieter & 1 & & & & & \\
\hline & & EQ-2 & Being dirtier or cleaner & 3 & 0,089 & 0,037 & 4 & 6 & 6 \\
\hline & & EQ-3 & Being more or less congested (human density) & 2 & 0,098 & 0,041 & 4 & 6 & 5 \\
\hline & & EQ-4 & Building quality, better or worse? & 4 & 0,057 & 0,024 & 3 & 7 & 6 \\
\hline \multirow{5}{*}{$\begin{array}{c}\text { Physical } \\
\text { Quality } \\
\text { [PQ] }\end{array}$} & \multirow{5}{*}{0,151} & PQ-1 & Quality of the built environment & 1 & 0,058 & 0,009 & 3 & 7 & 6 \\
\hline & & PQ-2 & Less abandoned spaces & 2 & 0,040 & 0,006 & 4 & 5 & 5 \\
\hline & & PQ-3 & Quality of parks and green spaces & 4 & 0,015 & 0,002 & 3 & 6 & 5 \\
\hline & & PQ-4 & Maintenance of residences and open spaces & 3 & 0,022 & 0,003 & 4 & 7 & 6 \\
\hline & & PQ-5 & Public realm quality & 5 & 0,015 & 0,002 & 3 & 5 & 5 \\
\hline \multirow{4}{*}{$\begin{array}{c}\text { Functional } \\
\text { Quality } \\
\text { [FQ] }\end{array}$} & \multirow{4}{*}{0,139} & FQ-1 & Convenient pedestrian circulation & 1 & 0,046 & 0,006 & 3 & 5 & 4 \\
\hline & & FQ - - & Quality of public transport & 4 & 0,024 & 0,003 & 3 & 4 & 5 \\
\hline & & FQ -3 & Low traffic speeds \&density & 2 & 0,042 & 0,006 & 3 & 5 & 4 \\
\hline & & FQ-4 & Vitality and viability of services\&urban amenities & 3 & 0,027 & 0,004 & 3 & 5 & 5 \\
\hline \multirow{2}{*}{$\begin{array}{c}\text { Safer Places } \\
\text { [SP] }\end{array}$} & \multirow{2}{*}{0,111} & SP-1 & Low crime rate & 1 & 0,077 & 0,009 & 3 & 6 & 5 \\
\hline & & SP-2 & Safety of life and property & 2 & 0,034 & 0,004 & 3 & 6 & 5 \\
\hline \multirow{4}{*}{$\begin{array}{c}\text { Social Connection } \\
\text { and Interaction at } \\
\text { Micro and Macro } \\
\text { Environment } \\
\text { [SCI] }\end{array}$} & \multirow{4}{*}{0,180} & SCI-1 & The number of relatives and friends living nearby & 1 & 0,096 & 0,017 & 3 & 5 & 5 \\
\hline & & SCI-2 & Good neighbourhood relations & 2 & 0,037 & 0,007 & 4 & 5 & 4 \\
\hline & & SCI - 3 & Feeling part of the community & 4 & 0,023 & 0,004 & 4 & 6 & 5 \\
\hline & & SCI-4 & Ensuring social integration / harmony & 3 & 0,025 & 0,004 & 3 & 6 & 4 \\
\hline \multicolumn{7}{|c|}{ Total Weight: } & 0,239 & 0,416 & 0,345 \\
\hline \multicolumn{7}{|c|}{ Normalized relative importance weight (\%) } & 23,9 & 41,6 & 34,5 \\
\hline \multicolumn{7}{|c|}{ R a n k i n $g$ : } & 3 & 1 & 2 \\
\hline
\end{tabular}

The evaluations of the expert groups are presented comparatively in Table 6 in order to reveal the weaknesses and strengths of the Karatay, Meram and Selçuklu districts in context of QoUL criteria.

Table 6. Experts' Performance Assessments Regarding the QoUL Criteria in Central Districts of Konya City (Karatay, Meram and Selçuklu)

\begin{tabular}{|l|l|c|c|c|c|c|c|}
\hline \multirow{2}{*}{} & \multirow{2}{*}{ QoUL C r i t e r i a : } & \multicolumn{2}{|c|}{ K a r a t a } & \multicolumn{2}{c|}{ M e r a m } & \multicolumn{2}{c|}{ S e I c u k l u } \\
\cline { 2 - 8 } & $\begin{array}{c}\text { Local } \\
\text { Authority } \\
\text { Experts }\end{array}$ & Academicians & $\begin{array}{c}\text { Local } \\
\text { Authority } \\
\text { Experts }\end{array}$ & Academicians & $\begin{array}{c}\text { Local } \\
\text { Authority } \\
\text { Experts }\end{array}$ & Academicians \\
\hline EQ-1 & Being noisier or quieter & 4,21 & 4,10 & 7,47 & 8,47 & 4,49 & 4,83 \\
\hline EQ-2 & Being dirtier or cleaner & 1,23 & 1,99 & 1,82 & 3,65 & 1,77 & 3,30 \\
\hline EQ-3 & Being more or less congested (human density) & 3,51 & 2,58 & 3,89 & 3,80 & 5,44 & 3,46 \\
\hline EQ-4 & Building quality, better or worse? & 1,68 & 1,09 & 2,79 & 2,45 & 2,77 & 2,15 \\
\hline PQ-1 & Quality of the built environment & 1,02 & 1,19 & 1,77 & 2,57 & 1,73 & 2,09 \\
\hline PQ-2 & Less abandoned spaces & 1,35 & 1,22 & 1,94 & 1,39 & 1,65 & 1,38 \\
\hline PQ-3 & Quality of parks and green spaces & 0,35 & 0,35 & 0,45 & 0,61 & 0,41 & 0,56 \\
\hline PQ-4 & Maintenance of residences and open spaces & 0,37 & 0,52 & 0,52 & 0,91 & 0,52 & 0,78 \\
\hline PQ-5 & Public realm quality & 0,40 & 0,34 & 0,56 & 0,60 & 0,52 & 0,57 \\
\hline FQ-1 & Convenient pedestrian circulation & 1,75 & 0,96 & 2,57 & 2,00 & 2,38 & 1,64 \\
\hline FQ-2 & Quality of public transport & 0,61 & 0,63 & 0,78 & 0,75 & 0,83 & 0,98 \\
\hline FQ-3 & Low traffic speeds \&density & 0,82 & 1,12 & 0,96 & 1,68 & 0,78 & 1,43 \\
\hline FQ-4 & Vitality and viability of services\&urban amenities & 1,03 & 0,67 & 1,38 & 0,96 & 1,42 & 1,06 \\
\hline SP-1 & Low crime rate & 1,53 & 1,53 & 2,50 & 3,29 & 2,05 & 2,90 \\
\hline SP-2 & Safety of life and property & 0,72 & 0,78 & 1,11 & 1,39 & 0,99 & 1,26 \\
\hline SCl-1 & The number of relatives and friends living nearby & 3,09 & 2,44 & 4,32 & 3,70 & 4,12 & 3,46 \\
\hline SCI-2 & Good neighbourhood relations & 0,81 & 1,16 & 1,04 & 1,40 & 0,99 & 1,09 \\
\hline SCI -3 & Feeling part of the community & 0,93 & 0,56 & 1,20 & 0,96 & 1,02 & 0,75 \\
\hline SCI-4 & Ensuring social integration / harmony & 0,97 & 0,64 & 1,43 & 1,04 & 1,25 & 0,82 \\
\hline
\end{tabular}

\begin{tabular}{|c|c|c|c|c|c|c|c|c|c|c|c|c|}
\hline \multirow{2}{*}{ TOTAL QOUL PERFORMANCE ASSESSMENT (\%): } & \multicolumn{4}{|c|}{ Karat ay } & \multicolumn{4}{|c|}{ M e r a m } & \multicolumn{4}{|c|}{ Selçuklu } \\
\hline & 䂞 & 26,4 & 太 & 23,9 & 梳 & 38,5 & 因 & 41,6 & 弐 & 35,1 & 床 & 34,5 \\
\hline
\end{tabular}

\section{Assessments of experts for QoUL in Karatay}

The weaknesses and strengths of Karatay (Table 6), which is evaluated as the worst district in terms of life QoUL criteria by LCAs (26.4\%) and academicians (23.9\%), are explained below.

By LCAs Karatay is thought to be more successful in terms of QoUL criteria such as [EQ-1] "Being noisier or quieter" (4.21\%), [EQ-3] "Being more or 
less congested" (3.51\%), [SCI-1] " The number of relatives and friends living nearby" (3.09\%), [FQ-1] "Convenient pedestrian circulation" (1.75\%), [EQ-4] "Building quality, better or worse" (1.68\%), [SP-1] "Low crime rate" (1.53\%) and [PQ-2] "Less abandoned spaces" (1.35\%). Academicians, on the other hand, have reported that Karatay is more successful in context of the criteria of [EQ-1] "Being noisier or quieter" (4.21\%), [EQ-3] "Being more or less congested" (3.51\%), [SCI-1] " The number of relatives and friends living nearby" (3.09\%), [EQ-2] "Being dirtier or cleaner" (1.99\%), [SP-1] “ Low crime rate" (1.53\%) and [PQ- 2] "Less abandoned spaces" (1.22\%).

LCAs consider that Karatay is weakness in terms of QoUL criteria of [SP-2] "Safety of life and property" (0.72\%), [FQ-2] "Quality of public transport" (0.61\%), [PQ-5] "Public realm quality" (0.40\%), [PQ-4] "Maintenance of residences and open spaces" (0.37\%) and [PQ-3] "Quality of parks and green spaces" (0.35\%). Academicians, on the other hand, have reported that Karatay is weakness in terms of QoUL criteria of [FQ-2] "Quality of public transport" (0.63\%), [SCI-3] "Feeling part of the community" (0.56\%), [PQ-4] "Maintenance of residences and open spaces" $(0.52 \%)$, [PQ-3] "Quality of parks and green spaces" (0.35\%) and [PQ-5] "Public realm quality" (0.34\%).

\section{Assessments of experts for QoUL in Meram}

The weaknesses and strengths of Meram (Table 6), which is rated as the best district in terms of life QoUL criteria by LCAs (38.5\%) and academicians (41.6\%), are explained below.

By LCAs Meram is thought to be more successful in terms of QoUL criteria such as [EQ-1] "Being noisier or quieter" (7.47\%), [SCI-1] " The number of relatives and friends living nearby" (4.32\%), [EQ-3] "Being more or less congested" (3.89\%), [EQ-4] "Building quality, better or worse" (2.79\%), [FQ-1] "Convenient pedestrian circulation" (2.57\%), [SP-1] "Low crime rate" (2.50\%) and [PQ-2] "Less abandoned spaces" (1.94\%). Academicians, on the other hand, have reported that Meram is more successful in context of the criteria of [EQ-1] "Being noisier or quieter" (8.47\%), [EQ-3] "Being more or less congested" (3.89\%), [SCI-1] " The number of relatives and friends living nearby" (3.70\%), [EQ-2] "Being dirtier or cleaner" (3.65\%), [SP-1]“ Low crime rate" (3.29\%), [PQ-1] "Quality of the built environment" (2.57\%), [EQ-4] " Building quality, better or worse?" (2.45\%) and [FQ-1] "Convenient pedestrian circulation" (\% 2.00).

LCAs consider that Meram is weakness in terms of QoUL criteria of [FQ-3] "Low traffic speeds \&density" (0.96\%), [FQ-2] "Quality of public transport" (0.78\%), [PQ-5] "Public realm quality" (0.56\%), [PQ-4] "Maintenance of residences and open spaces" (0.52\%) and [PQ-3] "Quality of parks and green spaces" (0.45\%). Academicians, on the other hand, have reported that Meram is weakness in terms of QoUL criteria of [FQ-4] "Vitality and viability of services and urban amenities" (0.96\%), [SCI-3] "Feeling part of the community" (0.96\%), [PQ-4] "Maintenance of 
residences and open spaces" (0.91\%), [FQ-2] "Quality of public transport" (0.75\%), [PQ-3] "Quality of parks and green spaces" (0.61\%) and [PQ- 5] "Public realm quality" (0.60\%).

\section{Assessments of experts for QoUL in Selçuklu}

The weaknesses and strengths of Selçuklu (Table 6), which is the district ranked second in terms of high QoUL criteria by LCAs (35.1\%) and academicians (34.4\%), are explained below.

Selçuklu is thought to be more successful in terms of QoUL criteria such as [EQ-3] "Being more or less congested" (5.44\%), [EQ-1] "Being noisier or quieter" (4.49\%), [SCI-1] " The number of relatives and friends living nearby" (4.12\%), [EQ-4] "Building quality, better or worse" (2.77\%), [FQ1] "Convenient pedestrian circulation" (2.38\%) and [SP-1] "Low crime rate" (2.05\%) by LCAs. Academicians, on the other hand, have reported that Selçuklu is more successful in context of the criteria of [EQ-1] "Being noisier or quieter" (4.83\%), [EQ-3] "Being more or less congested" (3.46\%), [EQ-2] "Being dirtier or cleaner" (3.30\%), [SP-1]" Low crime rate" (2.90\%), [EQ-4] " Building quality, better or worse?" (2.15\%) and [PQ-1] "Quality of the built environment" (2.09\%)

LCAs consider that Selçuklu is weakness in terms of QoUL criteria of [FQ2] "Quality of public transport" (0.83\%), [FQ-3] "Low traffic speeds \&density" (0.78\%), [PQ-5] "Public realm quality" (0.52\%), [PQ-4] "Maintenance of residences and open spaces" (0.52\%) and [PQ-3] "Quality of parks and green spaces" (0.41\%). Academicians, on the other hand, have reported that Selçuklu is weakness in terms of QoUL criteria of [SCI-4] "Ensuring social integration \& harmony" (0.82\%), [PQ-4] "Maintenance of residences and open spaces" (0.78\%), [SCI-3] "Feeling part of the community" (0.75\%), [PQ- 5] "Public realm quality" $(0.57 \%)$ and [PQ-3] "Quality of parks and green spaces" (0.56\%).

\section{CONCLUSIONS AND RECOMMENDATIONS}

This study, evaluated comparatively the QoUL of Karatay, Meram and Selçuklu districts from the point of two expert groups via AHP methodology. The findings show that from the perspective of two expert groups, Meram is the district with the highest QoUL, while Karatay is the district with the lowest QoUL. Although the expert groups have different priority weights on the basis of the criteria groups and sub-criteria and also each district has different performance scores in the context of the relevant criteria, the multi-criteria holistic QoUL rankings of both expert groups on the basis of districts are similar.

Performance determinations of the criteria, that are above the average QoUL value and increase in the relevant district's holistic QoUL criteria ranking, for Karatay, Meram and Selçuklu are presented at the below due to their priorities.

- For Meram the criteria of [EQ-1] "Being noisier or quieter", [SCI1] "The number of relatives and friends living nearby", [EQ-3] "Being more or less congested", [EQ-2] "Being dirtier or cleaner", 
[SP-1] "Low crime rate", [PQ-1] "Quality of the built environment", [EQ-4] "Building quality, better or worse", [FQ-1] "Convenient pedestrian circulation" and [PQ-2] "Less abandoned spaces".

- For Selçuklu the criteria of [EQ-3] "Being more or less congested", [EQ-1] "Being noisier or quieter", [SCI-1] "The number of relatives and friends living nearby", [EQ-2] "Being dirtier or cleaner", [SP1] "Low crime rate", [EQ-4] "Building quality, better or worse", [PQ-1] "Quality of the built environment", [FQ-1] "Convenient pedestrian circulation" and [FQ-1] "Convenient pedestrian circulation".

- For Karatay the criteria of [EQ-1] "Being noisier or quieter", [EQ3] "Being more or less congested", [SCI-1] "The number of relatives and friends living nearby" and [PQ-1] "Quality of the built environment".

Performance determinations of the criteria, that are under the average QoUL value and decrease in the relevant district's holistic QoUL criteria ranking, for Karatay, Meram and Selçuklu are presented at the below due to their priorities.

- For Karatay the criteria of [PQ-5] "Public realm quality", [PQ-4] "Maintenance of residences and open spaces", [PQ-3] "Quality of parks and green spaces", [FQ-2] "Quality of public transport" and [SCI-3] "Feeling part of the community".

- For Meram the criteria of [PQ-3] "Quality of parks and green spaces", [PQ-5] "Public realm quality", [PQ-4] "Maintenance of residences and open spaces", [FQ-2] "Quality of public transport" and [FQ-3] "Low traffic speeds \&density".

- For Selçuklu the criteria of [FQ-3] "Low traffic speeds \&density", [SCI-3] "Feeling part of the community", [PQ-5] "Public realm quality", [PQ-4] "Maintenance of residences and open spaces" and [PQ-3] "Quality of parks and green spaces".

Differences of opinion in the context of occupations of expert groups also differed their degrees of concern regarding QoUL sub-criteria and/or criteria groups. Although the views of LCAs who are mostly practitioners, and the academicians related with QoUL in a theoretical sense, differ in terms of criteria importance, similar findings derived via experts' holistic QoUL assessments indicate of both indicate an objective assessment.

Faced weaknesses of the districts against QoUL determined through the applied AHP based QoUL, should be strengthen. Objective indicators should also be adapted to overcome these problems. Also, the reasons for these criteria that reduce the quality of life should be questioned.

The findings clearly show the knowledge of which indicators need to be improved in order to create and increase QoUL, or which mitigation strategies should be more prioritised by policy makers and decision makers in the city on each district basis. Thus, separate and local planning strategies can be formulated for each district which are at different QoUL levels in order to create liveable urban areas which have high QoL in 
Konya. Besides, district-based highlighted indicators as high QoUL indicators by experts can be a starting point for districts that stay in the background in terms of overall QoUL rankings or in the context of the relevant indicator. Urban areas have good and very good QoUL indicators should be protected and also appropriate development and control arrangements should be adopted. In areas with moderate QoUL quality indicators should not be disrupted in the future by the preventive strategies of the authorities. In areas with inadequate and very poor QoUL, all planning measures and implementation strategies should be evaluated in order to improve quality at the highest possible level.

Within the light of low QoUL rates, in Karatay public realm quality and maintenance of residences and open spaces should be enhanced. Also, the public transportation facilities should be enhanced and improved. Built environment should support the social interactions of the community and esthetical environment quality.

In Meram district, which suffers from similar QoUL reduction problems with Karatay, strategies that increase the population and traffic density in a balanced way should be adopted in addition to the strategies stated. Similar with both districts, problems of decrease in parks, green spaces, public realm and public transport quality also problem of low traffic speeds and density should be tackled in Selçuklu district. In this context the quantity of green areas should be increased, public transportation opportunities should be increased, maintenance of residences and parks should be provided. Finally, strategies that increase the population and traffic density in a balanced way, should be adopted, as should be adopted for Meram, too.

Planning urban areas having high QoL, solving existing urban problems and improving the QoUL are the main concerns of planners and local administrators, and planning gains legitimacy with its contribution to the QoUL. In this context, research findings provide important contributions for decision-makers as the key stakeholders of urban development regarding Konya city such as; (i) to identify the strengths and weaknesses of the QoUL effectively thus to reveal the problems that require special attention and solution, (ii) to determine the direction and degree of the relationship between urban facilities and services and the urbanites and to compare them with subsequent measurements, (iii) providing information about the distribution of satisfaction and dissatisfaction in society and space, (iv) monitoring the effects of policies on the space, (v) determining effective policies that improve conditions in line with the determinations made for the current situation, and (vi) to guide local government units and other relevant stakeholders away on appropriate actions and transformations to increase the QoUL via developing effective policies against the problematic of QoUL decrease and create urban areas with high QoL. The method applied in the study is adaptable and can be applied to effectively evaluate the QoUL in other cities. 


\section{ACKNOWLEDGEMENTS/NOTES}

The earlier version of this manuscript [consisting pre-findings of pilot questionnaire case study] titled "Konya Kentinde Kentsel Yaşam Kalitesine İlişkin Uzman Görüşlerinin Incelenmesi" has been presented at II. International Academic Research Congress (18-21 October 2017, Alanya).

\section{CONFLICT OF INTEREST}

No conflict of interest was declared by the author.

\section{FINANCIAL DISCLOSURE}

The author declared that this study has received no financial support.

\section{ETHICS COMMITTEE APPROVAL}

Ethics committee approval was not required for this article.

\section{LEGAL PUBLIC/PRIVATE PERMISSIONS}

In this research, the necessary permissions were obtained from the relevant participants (individuals, institutions and organizations) during the questionnaire survey.

\section{REFERENCES}

Allen, N.M. (2016). Quality of urban life and intensification: Understanding housing choices, trade-offs, and the role of urban amenities [Doctoral Thesis, University of Auckland].

Antognelli S, Vizzari M., (2016). LISAM: an open source GIS-based model for liveability spatial assessment. PeerJ Preprints 4:e2133v2. https://doi.org/10.7287/peerj.preprints.2133v2

Architects Council of Europe-ACE. (2019). Achieving quality in the built environment. https://www.ace-cae.eu/fileadmin/New_Upload/_15_ EU_Project/Creative_Europe/Conference_Quality_2019/Inn_Stat_EN_FI NAL.pdf

Ataseven, A., \& Bakış, Ç. (2018). Türkiye'de sosyal uyum. İstanbul Politikalar Merkezi. http://ingev.org/raporlar/SosyalUyumRaporu.pdf

Atkins, P., Marson, R., \& Brann, B. (2015). State of Australian cities 20142015 progress in Australian regions. Department of Infrastructure and Regional Development, Commonwealth of Australia. https://www.infrastructure.gov.au/infrastructure/pab/soac/files/2015 _SoAC_full_report.pdf

Beck, H. (2009). Linking the quality of public spaces to quality of life. Journal of Place Management \& Development, 2(3), 240-248.

Carmona, M. (2019). Place value: place quality \& its impact on health, social, economic \& environmental outcomes. Journal of Urban Design, 24(1), 1-48. DOI:10.1080/13574809.2018.1472523

Chen, Z. (2020). Evaluating sustainable liveable city via multi-MCDM and Hopfield neural network. Mathematical Problems in Engineering, 2020, 1-11. DOI: $10.1155 / 2020 / 4189527$ 
Choon, S.W., Siwar, C., Pereira, J.J., Jemain, A.A., Hashim H.S., \& Hadi, A.S. (2011). A sustainable city index for Malaysia. International Journal of Sustainable Development \& World Ecology, 18(1), 28-35. https://doi.org/10.1080/13504509.2011.543012

Delsante, I. (2016). Urban environment quality assessment using a methodology \& set of indicators for medium-density neighbourhoods: a comparative case study of Lodi \& Genoa. Ambiente Construído, Porto Alegre, 16(3), 7-22.

Dempsey, N. (2008). Quality of the built environment in urban neighbourhoods. Planning Practice and Research, 23(2), 249-264.

Din, H.S.E., Shalaby, A., Farouh H. E., \& Elariane, S.A. (2013). Principles of urban quality of life for a neighborhood. HBRC Journal, 9(1), 86-92. DOI: 10.1016/j.hbrcj.2013.02.007

Dissanayake, D., Morimoto, T., Murayama, Y., Ranagalage, M., \& Perera, E. (2020). Analysis of life quality in a tropical mountain city using a multicriteria geospatial technique: A case study of Kandy City, Sri Lanka. Sustainability, 12(7), 2918. doi:10.3390/su12072918

Ganebnykh, E., Burtseva, T., Mironova, N., \& Feoktistova O. (2019, August 09). Quality assessment of urban environment [Paper presentation]. E3S Web of Conferences SPbWOSCE-2018 Business Technologies for Sustainable Urban Development, 110, St. Petersburg, Russia. https://doi.org/10.1051/e3sconf/201911001077

Güleç Solak, S. (2017). Mekân-Kimlik Etkileşimi: Kavramsal ve Kuramsal Bir Bakış. Manas Sosyal Araştırmalar Dergisi, 6(1), 13-37.

Harker, P.T., \& Vargas, L.G. (1987). The theory of ratio scale estimation: Saaty's analytic hierarchy process. Management Science, 33(11), 1383-1403.

Hollar, D. (2003). A holistic theoretical model for examining welfare reform: Quality of life. Public Administration Review, 63(1), 90-104.

Hoşgör, H., Söyük, S., \& Önder, E. (2016). İdari ve akademik personelin iş yaşam kalitesine etki eden faktörlerin öncelik sırasının belirlenmesi: Bir analitik hiyerarşi prosesi uygulaması. Akademik Sosyal Araştırmalar Dergisi, 31, 302-323.

Hsueh, S-L., \& Lin, Y-J. (2018). Critical success factors of the urban environmental quality. Ekoloji, 27(106), 217-222.

İnceoğlu, M., \& Aytuğ, A. (2009). Kentsel mekânda kalite kavramı. Megaron, 4(3), 131-146.

Karakayacı, Z. \& Karakayacı, Ö. (2019). Determination of urban sprawl effects on farmlands value using GIS. ICONARP International Journal of Architecture \& Planning, 7(2), 513-539.

Krishnan, S.V., \& Firoz, M.C. (2020). Regional urban environmental quality assessment \& spatial analysis. Journal of Urban Management, 9(2), 191-204.

Leby, J.L., \& Hashim, A.H. (2010). Liveability dimensions \& attributes: Their relative importance in the eyes of neighbourhood residents. Journal of Construction in Developing Countries, 15(1), 67-91. 
Lombardi, P., Giordano, S., Farouh, H., \& Yousef, W. (2012). Modelling the smart city performance. Innovation: The European Journal of Social Science Research, 25(2), 137-149. DOI: 10.1080/13511610.2012.660325

Lotfi, S., \& Solaimani, K. (2009). An assessment of urban quality of life by using analytic hierarchy process approach (case study: comparative study of quality of life in the north of Iran). Journal of Social Sciences 5(2), 123-133.

Lowe, M., Whitzman, C., Badland, H., Davern, M., Hes, D., Aye, L., Butterworth, I., \& Giles-Corti, B. (2013). Liveable, healthy, sustainable: What are the key indicators for Melbourne neighbourhoods? (Research Paper 1). University of Melbourne, Place, Health \& Liveability Research Program. https://communityindicators.net/resources/liveable-healthysustainable-what-are-the-key-indicators-for-melbourne-neighbourhood s/

MacLean, L., \& Salama, A. M. (2019). Towards a context specific and multidimensional quality of urban life model. Open House International, 44(1), 25-33.

Mangir, F. (2016). "Smart city" strategies for local governments: The case of Konya in Turkey. Sosyal Bilimler Meslek Yüksekokulu Dergisi, 19 (41. yll özel sayısı), 17-36.

Marans R.W., \& Stimson R. (2011). An overview of quality of urban life. In: R. Marans, R. Stimson (eds), Investigating Quality of Urban Life: Social Indicators Research Series Vol 45 (pp.1-29). Springer. https://doi.org/10.1007/978-94-007-1742-8_1

Marans, R.W. (2012). Quality of urban life studies: An overview and implications for environment-behaviour research. Procedia - Social and Behavioral Sciences, 35, 9-22.

McCrea, R., Stimson, R., \& Western, J. (2005). Testing a moderated model of satisfaction with urban living using data for Brisbane-South East Queensland, Australia. Social Indicators Research, 72(2), 121-152.

McCrea, R., Marans, R.W., Stimson, R., \& Western, J. (2011). Subjective Measurement of quality of life using primary data collection and the analysis of survey data. In: R. Marans, R. Stimson (eds), Investigating Quality of Urban Life: Social Indicators Research Series Vol 45 (pp. 55-75). Springer.

Merschdorf, H. (2014). Quality of urban life: A GIS-based analysis of the subjective and objective quality of urban life in Salzburg, Austria. AV Akademikerverlag.

Mevlana Kalkınma Ajansı-MEVKA. (2019). Konya-Karaman sosyoekonomik görünüm, Konya. https://www.mevka.org.tr/Yukle me/Uploads/DsyCxZprj413202091213PM.pdf

Michalos A.C. (eds) (2014). Encyclopedia of quality of life and well-being research. Springer.

Mohit, M.A. (2014). Present trends and future directions of quality-of-life. Procedia-Social and Behavioral Sciences, 153, 655-665.

Mousavi, S.M. (2013). Livability in historic urban quarters case study: Walled city of Famagusta [Master Thesis, Northern Cyprus Eastern Mediterranean University]. 
Murgaš, F., \& Klobučník, M. (2018). Quality of life in the city, quality of urban life or well-being in the city: Conceptualization and case study. Ekológia (Bratislava), 37(2), 183-200.

Onnom, W., Tripathi, N., Nitivattananon, V., \& Ninsawat, S. (2018). Development of a liveable city index (LCI) using multi criteria geospatial modelling for medium class cities in developing countries. Sustainability, 10,520 .

Özden, P.P. (2010). Kentsel yenilemenin unutulan öğesi: Toplumsal yenilenme, In Ö. Uğurlu, N.Ş. Pınarcıklığlu, A. Kanbak, \& M. Şiriner (Eds.), Türkiye perspektifinden kent sosyolojisi çalışmaları (pp. 267-308). Örgün Yayınevi.

Pacione, M. (2003). Quality-of-life research in urban geography. Urban Geography, 24(4), 314-339. DOI: 10.2747/0272-3638.24.4.314

Papachristou, I., \& Rosas-Casals, M. (2015, Jun 29-Jul 01). An integrative methodology for the quality of life measurement in urban places based on the accomplishment of human needs [Paper presentation]. UN-Habitat Future of Places III Conference, Stockholm, Sweden. http://hdl.handle.net/2117/83018

Parkinson, M., Champion, T., Simmie, J., Turok, I., Crookston, M., Yeang, L.D., Katz, B., Park, A., Berube, A., Coombes, M.,Dorling, D., Evans, R., Glass, N., Hutchins, M., Kearns, A., Martin, R., \& Wood, P. (2006). State of the English cities: A research study (Volume 1). Office of the Deputy Prime Minister (ODPM). ISBN: 10 1-851128-45-X, 13 978185112845-7. London.

Psatha, E., Deffner, A., \& Psycharis, Y. (2011). Defining the quality of urban life: Which factors should be considered? [Paper presentation]. European Regional Science Association 51st European Congress, Barcelona, Spain. https://ideas.repec.org/p/wiw/wiwrsa/ersa11p785.html

Rezvani, M., Mansourian, H., \& Sattari, M. (2013). Evaluating quality of life in urban areas (case study: Noorabad city, Iran). Social Indicators Research, 112(1), 203-220.

Saaty, T.L. (1990). How to make a decision: The analytic hierarchy process. European Journal of Operational Research, 48, 9-26. http://dx.doi.org/10.1016/0377-2217(90)90057-I

Saaty, T.L. (2003). Decision-making with the AHP: why is the principal eigenvector necessary. European Journal of Operational Research, 145 (1): 85-91.

Saaty, T.L. (2008). Decision making with the analytic hierarchy process. International Journal of Services Sciences. 1(1), 83-98.

Salihoğlu, T. (2012). Kentsel yaşam kalitesi araştırmaları. In M. Ersoy (Ed.), Kentsel Planlama Ansiklopedik Sözlük (pp. 264-266). Ninova Yayıncılık.

Salihoğlu T. (2016). Kentsel yaşam kalitesinin yükseltilmesinde boş zaman aktivitelerinin rolü: İstanbul örneği [Doctoral Thesis, İstanbul Teknik Üniversitesi].

Salihoğlu, T., \& Türkoğlu, H. (2019). Konut çevresi ve kentsel yaşam kalitesi. Megaron, 14(Suppl. 1), 203-217. DOI: 10.5505/MEGARON.2018.06977 
Sarı, V.İ., \& Kındap, A. (2018). Türkiye'de kentsel yaşam kalitesi göstergelerinin analizi. Sayıștay Dergisi,108, 39-72.

Serdaroğlu Sağ, N. (2021). Assessment of urban development pattern and urban sprawl using Shannon's entropy: A case study of Konya (Turkey). Journal of Human Sciences, 18(2), 252-265. doi:10.14687/jhs.v18i2.6158

Shamsuddin, S., \& Abu Hassan, N.R. (2013). Liveability of Kuala Lumpur city centre from the perspective of urban design quality. In S.S., Zubir \& C.A. Brebbia (Eds.), WIT Transactions on Ecology \& The Environment, Vol 179, The Sustainable City VIII (Volume 2) (pp. 1261-1270). WIT Press. doi:10.2495/SC131072

Silva, L.T., \& Mendes, J.F.G. (2012). City noise-air: An environmental quality index for cities. Sustainable Cities \& Society, 4, 1-11.

Sitorus, F., Cilliers, J.J., \& Brito-Parada, P.R. (2019). Multi-criteria decision making for the choice problem in mining and mineral processing: Applications and trends. Expert Systems with Applications, 121, 393-417.

Stimson R., \& Marans R.W. (2011). Objective measurement of quality of life using secondary data analysis. In: R. Marans, R. Stimson (eds), Investigating Quality of Urban Life: Social Indicators Research Series Vol 45 (pp. 33-53). Springer. https://doi.org/10.1007/978-94-007-1742-8_2

T.C. Kalkınma Bakanlığı / Turkish Republic, Ministry of Development. (2018). On birinci kalkınma planı (2019-2023) kentsel yaşam kalitesi özel ihtisas komisyonu raporu (Yayın No: KB: 3014-ÖİK: 795). Ankara.

Tapsuwan, S., Mathot, C., Walker, I., \& Barnett, G. (2018). Preferences for sustainable, liveable and resilient neighbourhoods and homes: A case of Canberra, Australia. Sustainable Cities and Society, 37, 133-145.

Tekeli, İ., Güler, C., Vaizoğlu, S., Algan, N., \& Kaya Dündar, A. (2004). Yaşam kalitesi göstergeleri: Türkiye için bir veri sistemi önerisi (TÜBA Raporları No:6). Türkiye Bilimler Akademisi. Ankara.

Turan, C., \& Erdönmez Dinçer, E. (2017). Kamusal alan okumaları Berlin Potsdamer Platz / Pariser Platz örnekleri. In E. Erdönmez Dinçer, \& A. Atmaca Can (Eds.), Kamusal alan okumalari: Esenler (Yayın No: 13) (pp. 41-63). Esenler Belediyesi Şehir Düşünce Merkezi Şehir Yayınları. İstanbul.

Türkiye İstatistik Kurumu / Turkish Statistical Institute-TSI. (2015). Illerde yaşam endeksi il sıralamaları ve endeks değerleri. http://tuik.gov.tr/PreTablo.do?alt_id=1106

Türkiye İstatistik Kurumu /Turkish Statistical Institute-TSI. (2019). Adrese dayalı nüfus kayıt sistemi sonuçları/Address Based Population Registration System. https://biruni.tuik.gov.tr/

Türkoğlu, H., Bölen, F., Baran, K.P., \& Robert Marans, R. (2006, July 2-5). Measuring quality of urban life: findings from Istanbul metropolitan study [Paper presentation]. ENHR conference Housing in an expanding Europe: theory, policy, participation and implementation, Ljubljana, Slovenia, 2-5 July 2006

Türkoğlu, H.D., Bölen, F., Baran, P. K., \& Marans, R. W. (2008). İstanbul'da yaşam kalitesinin ölçülmesi. itüdergisi/a mimarlık, planlama, tasarım, $7(2), 103-113$. 
Włodarczyk, K. (2015). Quality of urban life in Poland. Journal of International Studies, 8(2), 155-163.

World Health Organization-WHO. (2020, August 15). WHOQOL: Measuring quality of life. https://www.who.int/healthinfo/survey /whoqol-qualityoflife/en/

Yacan, İ. (2016). Eğitim kalitesinin belirlenmesinde etkili olan faktörlerin bulanık AHP ve bulanık TOPSiS yöntemi ile değerlendirilmesi [Master Thesis, Pamukkale Üniversitesi]

Yavuz, F. (2017). Konya kentinde kentsel yaşam kalitesine ilişkin uzman görüşlerinin incelenmesi. In II. International Academic Research Congress Abstracts Book (INES 2017, 18-21 October 2017, Alanya, Antalya), E. Hamarta, C. Arslan, S. Çiftçi, S. Avşaroğlu, O. Köksal, M. Uslu (Eds.) (pp. 566). ISBN: 978-605-196-092-0. Çizgi Kitabevi. Konya. http://www.cizgikitabevi.com/kitap/726-ines-abstracts-book

Yavuz, F. (2021). Urban sprawl: An empirical analysis for Konya Province Turkey. A/Z ITU Journal of the Faculty of Architecture, 18(1), 79-97, doi: 10.5505/itujfa.2020.04834

Yeang, L.D. (2006). Quality of place: The north's residential offer; Leeds city region. Llewelyn Davies Yeang Architecture Planning Design.

Yıldız, A, Ayyıldız, E, Taşkın Gümüş, A., \& Özkan, C. (2019). Ülkelerin yaşam kalitelerine göre değerlendirilmesi için hibrit pisagor bulanik ahptopsis metodolojisi: Avrupa Birliği Örneği. Avrupa Bilim ve Teknoloji Dergisi, 17, 1383-1391. DOI: 10.31590/ejosat.658021

\section{Resume}

Fadim Yavuz currently works at Necmettin Erbakan University, Department of Urban and Regional Planning, since 2012. She got her bachelor's degree in 2001, master degree in 2004 and Ph.D. degree in 2011 from Department of Urban and Regional Planning of Selçuk University. She received her Associate Professor Degree in 2021. She worked at Selçuk University in the years of 2001-2012. She is conducting research activities in the areas of participatory watershed planning \& management, sustainability, quality of urban life and decision making with analytic hierarchy process (AHP). 